\title{
ROS-mediated abiotic stress-induced programmed cell death in plants
}

\author{
Veselin Petrov' ${ }^{1}$, Jacques Hille ${ }^{2}$, Bernd Mueller-Roeber ${ }^{3}$ and Tsanko S. Gechev ${ }^{1,3}$ * \\ ${ }^{1}$ Institute of Molecular Biology and Biotechnology, Plovdiv, Bulgaria \\ ${ }^{2}$ Department of Pharmacy, Faculty of Mathematics and Natural Sciences, University of Groningen, Groningen, Netherlands \\ ${ }^{3}$ Department of Molecular Biology, Institute of Biochemistry and Biology, University of Potsdam, Potsdam-Golm, Germany
}

\section{Edited by:}

Patrick Gallois, University of

Manchester, UK

\section{Reviewed by:}

Vasileios Fotopoulos, Cyprus

University of Technology, Cyprus

Robert Fluhr, Weizmann Institute of

Science, Israel

\section{${ }^{*}$ Correspondence:}

Tsanko S. Gechev, Institute of Molecular Biology and Biotechnology, Ruski Boulevard 105, Plovdiv 4000, Bulgaria

e-mail: tsangech@uni-plovdiv.bg
During the course of their ontogenesis plants are continuously exposed to a large variety of abiotic stress factors which can damage tissues and jeopardize the survival of the organism unless properly countered. While animals can simply escape and thus evade stressors, plants as sessile organisms have developed complex strategies to withstand them. When the intensity of a detrimental factor is high, one of the defense programs employed by plants is the induction of programmed cell death (PCD). This is an active, genetically controlled process which is initiated to isolate and remove damaged tissues thereby ensuring the survival of the organism. The mechanism of PCD induction usually includes an increase in the levels of reactive oxygen species (ROS) which are utilized as mediators of the stress signal. Abiotic stress-induced PCD is not only a process of fundamental biological importance, but also of considerable interest to agricultural practice as it has the potential to significantly influence crop yield. Therefore, numerous scientific enterprises have focused on elucidating the mechanisms leading to and controlling PCD in response to adverse conditions in plants. This knowledge may help develop novel strategies to obtain more resilient crop varieties with improved tolerance and enhanced productivity. The aim of the present review is to summarize the recent advances in research on ROS-induced PCD related to abiotic stress and the role of the organelles in the process.

Keywords: abiotic stress, programmed cell death, reactive oxygen species, signal transduction, stress adaptation

\section{INTRODUCTION}

All organisms need to cope with numerous stress factors throughout their lives by employing a wide variety of defensive strategies. While mobile individuals can in many cases just evade them, plants as sessile beings have developed sophisticated morphological, biochemical, and physiological adaptations in order to survive the detrimental effects of the environment (Hirayama and Shinozaki, 2010). To ensure proper and appropriate responses they have evolved sensitive detection systems and robust signal transduction mechanisms. Moreover, the different protective measures are triggered in a highly specific and tightly controlled manner so that adequate reactions are guaranteed without an excessive waste of resources.

Plants face two principle types of stresses, biotic and abiotic, both of which can be deleterious. A wide spectrum of bacteria, fungi, and viruses attack plants at various stages of their development and the severity of the biotic stress may be altered by abiotic stress when it acts in parallel on the plant (Bostock et al., 2014). The latter includes extreme temperatures, high salinity, excessive light, water deprivation, pollutants such as ozone and herbicides, high concentrations of heavy metals, excessive UV radiation, and others (Gill and Tuteja, 2010). A common feature of the plants' responses towards all these stressors is the production of the so called reactive oxygen species (ROS; Jaspers and Kangasjarvi, 2010). These are formed by the incomplete reduction (hydrogen peroxide $-\mathrm{H}_{2} \mathrm{O}_{2}$; superoxide radical $-\mathrm{O}_{2}^{\bullet-}$; hydroxyl radical -
$\mathrm{HO}^{\bullet}$, etc.) or excitation ( singlet oxygen $-{ }^{1} \mathrm{O}_{2}$ ) of molecular oxygen (Gechev et al., 2006) and are strong oxidizers that can react with and damage a large variety of biological molecules (Petrov and Van Breusegem, 2012). They are regarded as byproducts of the aerobic way of life and are generated in different cellular compartments like chloroplasts, mitochondria and peroxisomes (Apel and Hirt, 2004). Despite their potential toxicity, ROS actually have a dual role in vivo depending on their concentration, site and duration of action, previous exposures to stress, etc. (Miller et al., 2010). In general, lower doses of ROS are employed as signals that mediate at least part of the responses towards stress while at higher concentrations they pose a significant threat that may eventually lead to programmed cell death (PCD; Gechev and Hille, 2005; Figure 1).

Programmed cell death is an active, genetically controlled process in which cells are selectively eliminated in a highly coordinated, multi-step fashion through the involvement of specific proteases and nucleases. Thus, only cells that are destined to die are destroyed and no damage to the neighboring cells is inflicted. Notably, PCD is central to a number of processes in non-stress conditions like the differentiation of tracheary elements, the formation of trichomes and root aerenchyma, abscission of floral organs, embryo formation, shaping the morphology of certain leaves, and many others (Gadjev et al., 2008). The balance between $\mathrm{PCD}$ and cell proliferation/elongation determines the growth rate of plant tissues (Van Breusegem and Dat, 2006). Hence, PCD 


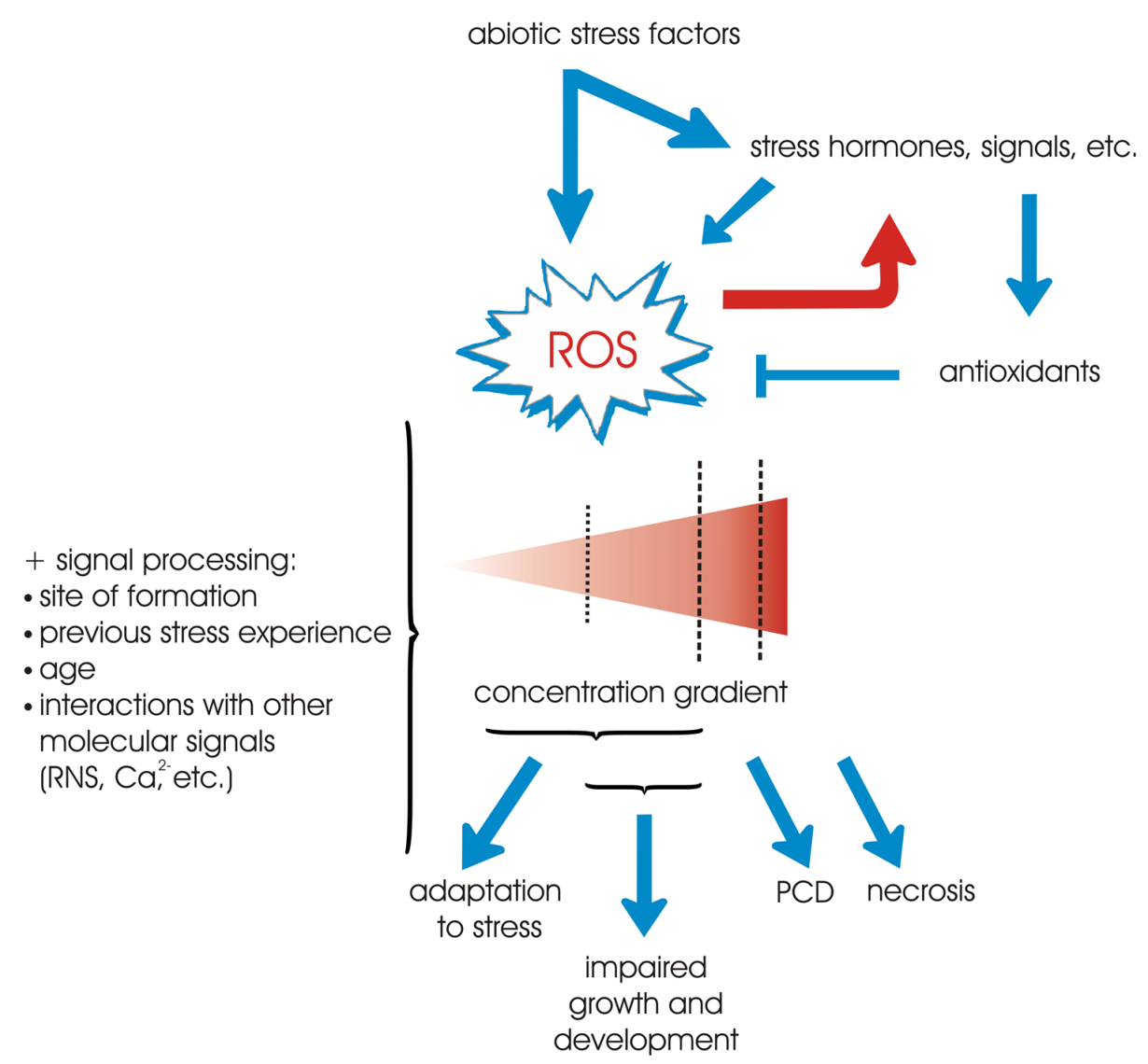

FIGURE 1 |An overview of the central role of ROS in the responses towards abiotic stress factors. Different abiotic cues either directly or indirectly (through the action of other signals and hormones) lead to the production of ROS. In turn, ROS may influence a variety of signal transduction systems, thus providing positive or negative feedback control mechanisms (red arrow). The function of the antioxidant machinery is to prevent dangerous elevations of ROS levels. The outcome of ROS signaling depends mainly on the ROS concentration, but other factors like the site of
ROS synthesis, previous stress exposure, developmental stage, and interaction with other signals like reactive nitrogen species (RNS) and $\mathrm{Ca}^{2+}$ are also integrated into the response. In general relatively weak stressors cause only a slight rise in ROS quantities which leads to adaptation. At more intensive abiotic stimuli the price for adaptation may be impaired growth and development of the plant. Severe stress usually causes massive accumulation of ROS and the initiation of PCD, or in extreme cases even necrosis of the tissue. is vital for normal growth and development of plants. On the other hand, PCD can be a consequence of severe abiotic and biotic stresses. Stress-induced PCD significantly affects plant yield and productivity and is therefore of fundamental importance to agriculture (Mittler and Blumwald, 2010). The changing climate conditions, combined with the expanding World's population and the limited potential to increase the area of arable land, has driven both fundamental and applied research on stress responses and stress-induced PCD with the ultimate goal to minimize yield losses caused by environmental stresses (Cominelli et al., 2013; Rosenzweig et al., 2014). The aim of the present review is to summarize the recent advances made in the field of abiotic-stress induced PCD and especially the roles of ROS as signaling mediators in this phenomenon. Genes involved in these processes are listed in Table 1; we refer to many of them in the following text.

\section{ROS-INDUCED PCD AGAINST PARTICULAR ABIOTIC STIMULI} Plants respond to specific abiotic stresses in a manner that depends on the identity of the stress factor. Although some of the mechanisms, like the induction of ROS production (Jaspers and Kangasjarvi, 2010), are common and overlap between different kinds of abiotic cues (and even biotic stresses), some of the utilized signal transduction networks, recruited transcription factors (TFs), and modulated genes are specific for each kind of stress. Moreover, recent evidence shows that when subjected to a combination of multiple stresses, plants respond differently than when experiencing only a single type of stress (Mittler and Blumwald, 2010; Atkinson and Urwin, 2012). The study of reactions to multiple stresses will in the future be of particular interest, since in the field crops are often confronted by a combination of detrimental abiotic factors.

\section{DROUGHT STRESS-INDUCED PCD}

Drought is among the abiotic factors that most strongly affect plant productivity and cause serious losses to crop yield (Godfray et al., 2010; Tester and Langridge, 2010). During water deprivation energy supply is severely restricted and ROS balance is impaired (Baena-Gonzalez et al., 2007; Miller et al., 2010). Not surprisingly, 
Table 1 | Proteins that participate in the control of PCD processes provoked by different abiotic stresses.

\begin{tabular}{|c|c|c|c|}
\hline Name & Function/activity & Related abiotic stresses & Reference \\
\hline $\begin{array}{l}\text { VPE, vacuolar processing } \\
\text { enzyme }\end{array}$ & A PCD-executing protease & Salt, osmotic, heat, ER-stress & $\begin{array}{l}\text { Li et al. (2012), Mendes etal. (2013), } \\
\text { Kim etal. (2014) }\end{array}$ \\
\hline BCL-2, B-cell lymphoma 2 & Suppressor of VPE & Salt, osmotic stress & Kim et al. (2014) \\
\hline $\begin{array}{l}\text { AtCYSa and AtCYSb, } \\
\text { cystatins }\end{array}$ & Cysteine protease inhibitors & Salt, drought, cold, oxidative stress & Zhang etal. (2008) \\
\hline $\begin{array}{l}\text { AtBOI, Botrytis susceptible1 } \\
\text { interactor }\end{array}$ & $\begin{array}{l}\text { Ubiquitinates BOS1, a transcription } \\
\text { factor (TF) implicated in stress } \\
\text { responses }\end{array}$ & Salt stress & Luo et al. (2010) \\
\hline $\begin{array}{l}\text { AtHSFA2, heat shock factor } \\
\text { A2 }\end{array}$ & $\begin{array}{l}\text { Alleviates oxidative stress during heat } \\
\text { shock }\end{array}$ & Heat stress & Zhang et al. (2009a) \\
\hline $\begin{array}{l}\text { mtHSP70, } 70 \text { kDa heat } \\
\text { shock protein (HSP) }\end{array}$ & Maintains $\Delta \Psi \mathrm{m}$ & Heat stress & Qi et al., 2011 \\
\hline AtKOD, kiss of death & $\begin{array}{l}\text { A peptide that induces } P C D \text { responses } \\
\text { upstream of mitochondrial dysfunction }\end{array}$ & Heat, oxidative stress & Blanvillain et al. (2011) \\
\hline AtMPK6, MAP kinase 6 & $\begin{array}{l}\text { Upregulates VPE, part of the } \\
\text { UVR8-independent pathway, drives } \\
\text { responses to } \mathrm{Cd}^{2+}\end{array}$ & Heat, high UV, $\mathrm{Cd}^{2+}$-stress & $\begin{array}{l}\text { Gonzalez Besteiro etal. (2011), Li etal. } \\
\text { (2012), Jin etal. (2013) }\end{array}$ \\
\hline $\begin{array}{l}\text { AtLSD1, lesion simulating } \\
\text { disease resistance } 1\end{array}$ & $\begin{array}{l}\text { Negative regulator of } P C D \text {, interacts } \\
\text { with catalases }\end{array}$ & Cold, UV-C, high-light stress & $\begin{array}{l}\text { Dietrich etal. (1997), Muhlenbock etal. } \\
\text { (2008), Huang etal. (2010), Wituszynska } \\
\text { etal. (2014), }\end{array}$ \\
\hline $\begin{array}{l}\text { AtDEAR1, DREB and EAR } \\
\text { motif protein } 1\end{array}$ & Transcriptional repressor of DREB & Cold stress & Tsutsui etal. (2009) \\
\hline AtMPK3, MAP kinase 3 & $\begin{array}{l}\text { Involved in the UVR8-independent } \\
\text { stress pathway }\end{array}$ & UV stress & Gonzalez Besteiro et al. (2011) \\
\hline AtMC8, metacaspase 8 & $\begin{array}{l}\text { A part of the PCD pathway provoked by } \\
\text { UV-radiation }\end{array}$ & UV-stress & He et al. (2008) \\
\hline $\begin{array}{l}\text { AtEDS1, enhanced disease } \\
\text { susceptibility } 1\end{array}$ & $\begin{array}{l}\text { Controls processes that extinguish } \\
\text { excess energy, triacylglycerol lipase }\end{array}$ & UV-C, high light stress & $\begin{array}{l}\text { Muhlenbock etal. (2008), Wituszynska } \\
\text { etal. (2014) }\end{array}$ \\
\hline $\begin{array}{l}\text { AtPAD4, phytoalexin } \\
\text { deficient } 4\end{array}$ & $\begin{array}{l}\text { Regulator in PCD pathway controlled by } \\
\text { LSD1, triacylglycerol lipase }\end{array}$ & High-light stress & Wiermer et al. (2005) \\
\hline $\begin{array}{l}\text { AtPARP, poly(ADP-ribose) } \\
\text { polymerase }\end{array}$ & $\begin{array}{l}\text { Synthesizes ADP-ribose polymers, } \\
\text { using } \mathrm{NAD}^{+} \text {as a substrate }\end{array}$ & High-light, drought, heat stress & De Block etal. (2005) \\
\hline AtNTL -4, TF & $\begin{array}{l}\text { Enhances ROS production during } \\
\text { drought-induced senescence and heat } \\
\text { stress }\end{array}$ & Drought, heat stress & Lee etal. $(2012,2014)$ \\
\hline $\begin{array}{l}\text { AOX1a, alternative oxidase } \\
\text { 1a }\end{array}$ & Mitigates mitochondrial ROS burst & Al stress & Liu et al. (2014) \\
\hline AtEXECUTER 1 and 2 & Drives effects after ${ }^{1} \mathrm{O}_{2}$ accumulation & ${ }^{1} \mathrm{O}_{2}$ stress & Lee etal. (2007) \\
\hline $\begin{array}{l}\text { AtSOLDAT, singlet } \\
\text { oxygen-linked death activator }\end{array}$ & Suppresses ${ }^{1} \mathrm{O}_{2}$-induced cell death & ${ }^{1} \mathrm{O}_{2}$ stress & $\begin{array}{l}\text { Coll etal. (2009), Meskauskiene et al. } \\
\text { (2009) }\end{array}$ \\
\hline AtANAC013, TF & $\begin{array}{l}\text { Conveys information about } \\
\text { mitochondrial dysfunction }\end{array}$ & Mitochondrial stress & De Clercq etal. (2013) \\
\hline AtbZIP28, TF & $\begin{array}{l}\text { Transduces the UPR-response; part of } \\
\text { the heat shock tolerance pathway }\end{array}$ & Heat, ER stress & Liu etal. (2007), Gao etal. (2008a) \\
\hline
\end{tabular}


Table 1 | Continued

\begin{tabular}{|c|c|c|c|}
\hline Name & Function/activity & Related abiotic stresses & Reference \\
\hline AtbZIP60, TF & $\begin{array}{l}\text { Transduces the UPR-response; } \\
\text { important for salt stress tolerance }\end{array}$ & Salt, ER stress & $\begin{array}{l}\text { Iwata and Koizumi (2005), Fujita et al. } \\
\text { (2007) }\end{array}$ \\
\hline AtNAC089, TF & Induces ER-triggered PCD & ER stress & Yang et al. (2014) \\
\hline $\begin{array}{l}\text { GmNAC30 and GmNAC81, } \\
\text { TFs }\end{array}$ & $\begin{array}{l}\text { Switch on VPE expression after ER and } \\
\text { osmotic stress }\end{array}$ & Osmotic, ER stress & Mendes etal. (2013) \\
\hline Bl-1, Bax-inhibitor 1 & Antiapoptotic protein in the ER & ER stress & $\begin{array}{l}\text { Watanabe and Lam (2006), Isbat et al. } \\
\text { (2009) }\end{array}$ \\
\hline $\begin{array}{l}\text { AtBiP2, ER luminal binding } \\
\text { protein } 2\end{array}$ & $\begin{array}{l}\text { ER chaperone protein, negative } \\
\text { regulator of } P C D\end{array}$ & $\mathrm{Cd}^{2+}$ stress & Xu et al. (2013) \\
\hline $\begin{array}{l}\text { AtTCTP, translationally } \\
\text { controlled tumor protein }\end{array}$ & $\begin{array}{l}\text { Inhibits PCD progression, probably by } \\
\text { sequestering } \mathrm{Ca}^{2+}\end{array}$ & Cold, salt, drought, Al stress & Hoepflinger et al. (2013) \\
\hline $\begin{array}{l}\text { AtUCP1, uncoupling } \\
\text { protein } 1\end{array}$ & $\begin{array}{l}\text { Uncouples } e^{-} \text {transport from ATP } \\
\text { synthesis }\end{array}$ & Salt, drought stress & Begcy etal. (2011) \\
\hline $\begin{array}{l}\text { ZmABP9, ABRE binding } \\
\text { protein } 9\end{array}$ & $\begin{array}{l}\text { Controls ABA signaling and ROS } \\
\text { accumulation }\end{array}$ & Drought, salt, cold stress & Zhang etal. (2011) \\
\hline
\end{tabular}

in the field drought usually occurs in combination with heat and their simultaneous action has a synergistic detrimental effect on plant productivity (Rampino et al., 2012). Prolonged drought stress is often associated with ROS accumulation, mainly due to decreased $\mathrm{CO}_{2}$ fixation concomitant with increased electron leakage to triplet oxygen which may eventually lead to PCD (Gechev et al., 2012). Fully functional ROS detoxifying systems are therefore of essential importance for the tolerance of plants towards drought and desiccation (Kranner et al., 2002). Therefore one of the main strategies to restrict ROS propagation and avoid unnecessary PCD under drought is to reduce ROS formation by downregulating chlorophyll synthesis and other components of the photosynthetic machinery (Farrant et al., 2007). Another factor that contributes to proper protection in these conditions is a well-balanced sucrose metabolism (Liu et al., 2013b). Sucrose fuels the glycolytic pathway which in turn feeds the oxidative pentose phosphate pathway. The latter produces reducing power (NADPH) which is needed for the synthesis of many non-enzymatic antioxidants including glutathione, ascorbic acid and flavonoids that are able to scavenge ROS (Bolouri-Moghaddam et al., 2010). In support of this hypothesis comes the finding that in two different cultivars of soybean the activities of glucose-6-phosphate dehydrogenase, a central enzyme of the pentose phosphate pathway, correlate with activities of the antioxidant enzymes glutathione reductase (GR), moodehydroascorbate reductase (MDHAR), and dehydroascorbate reductase (DHAR; Liu et al., 2013a). Sucrose as well as raffinose family oligosaccharides, which accumulate during dehydration, can also act as compatible solutes to protect from drought stress (Farrant et al., 2007). In addition, galactinol and raffinose can directly protect plants from oxidative stress as shown in Arabidopsis plants overexpressing galactinol synthase where elevated levels of galactinol and raffinose correlated with an increased tolerance to paraquat and abiotic stress (Nishizawa et al., 2008). Furthermore, both galactinol and raffinose can scavenge $\mathrm{HO}^{\bullet}$ in vitro (Nishizawa et al., 2008).

An important physiological adaptation during drought is the induction of leaf senescence. This process is executed by ROS-triggered PCD in selected leaves which allows nutrient remobilization and an overall reduction of the transpiratory surface. The phytohormones abscisic acid (ABA) and cytokinins also contribute to this phenomenon (Munné-Bosch and Alegre, 2004). Root tip meristems may also be affected by PCD as indicated by the degradation of organelles, an increased size of the vacuole and plasmalemma collapse during dehydration in Arabidopsis thaliana (Duan et al., 2010). This is an adaptive mechanism that is switched on to promote the development of lateral roots with enhanced stress tolerance which are important for post-stress recovery.

A prominent problem that occurs during periods of water deficit and other abiotic stresses is microspore abortion resulting in male sterility, which is due to the extreme sensitivity of the male reproductive program to adverse environmental conditions. This may be attributed to the increase in ROS concentrations following periods of drought and the subsequent PCD of the microspores (De Storme and Geelen, 2014). For example, when rice anthers are exposed to a short-term drought treatment accumulation of $\mathrm{H}_{2} \mathrm{O}_{2}$ is observed, accompanied by a reduced level of transcripts of antioxidant enzymes as well as ATP depletion. All these changes ultimately lead to PCD in developing anthers as confirmed by DNA fragmentation in these tissues (Nguyen et al., 2009).

Endogenous $\mathrm{ABA}$, which regulates stomatal closure and thus $\mathrm{CO}_{2}$ uptake, rapidly accumulates during periods of water deprivation (Osakabe et al., 2014). The signaling pathway stimulated by ABA in guard cells at first leads to a boost of ROS production, 
which in turn provokes an increase in the cytosolic $\mathrm{Ca}^{2+}$ concentration. Subsequently, activation of anion and $\mathrm{K}^{+}$efflux from the cell through specific ion channels results in the reduction of the guard cell turgor and thereby stomatal closure (Kwak et al., 2003). This process, however, is an example of a beneficial function of ROS which does not necessarily culminate in PCD. Another drought stress response mechanism in which ABA is implicated is the reorientation of polyamine (PA) metabolism in certain species like grapevine. In this case ABA induces PA accumulation and extrusion to the apoplast, where the PAs are then targeted by apoplastic amine oxidases. One of the products of the following reaction is $\mathrm{H}_{2} \mathrm{O}_{2}$, which may orchestrate further stress responses or induce PCD when present in high concentrations (Toumi et al., 2010).

\section{SALT/OSMOTIC-STRESS INDUCED PCD}

This kind of stress increases ROS concentrations and possibly leads to PCD by different mechanisms. In C3 plants the main source of ROS is the accelerated rate of photorespiration, which contributes to up to $70 \%$ of the accumulated $\mathrm{H}_{2} \mathrm{O}_{2}$ (Noctor et al., 2002). In C4 and CAM plants photorespiration proceeds in a negligible pace, which makes the chloroplast electron transport chain the main ROS producer. Moreover, during osmotic stress NADPH oxidases and apoplastic diamine and PA oxidases are activated as is mitochondrial respiration, which further elevates ROS concentration (Abogadallah, 2010). NADPH oxidase-produced superoxide anions are necessary for the execution of a PCD program switched on by both $\mathrm{NaCl}$ and sorbitol in tobacco cells (Monetti et al., 2014). However, the molecular reactions following the ionic $\mathrm{NaCl}$ and non-ionic sorbitol treatments do not completely overlap (Monetti et al., 2014) which suggests that these responses are highly specific. PA oxidases contribute directly to the $\mathrm{H}_{2} \mathrm{O}_{2}$ load in the apoplast since they catabolize PAs like spermidine, which are extruded into the apoplasts under high salinity, and produce $\mathrm{H}_{2} \mathrm{O}_{2}$ as a byproduct (Moschou et al., 2008). Salinity-provoked PCD is not restricted to higher plants, as demonstrated by Affenzeller et al. (2009), who report this phenomenon in the freshwater green alga Micrasterias denticulata.

An important feature of salt-induced PCD is that it is strongly affected by ion disequilibrium and may be the result of invasion of $\mathrm{Na}^{+}$into the cytosol accompanied by a deficiency of $\mathrm{K}^{+}$ (Kim et al., 2014). The efflux of $\mathrm{K}^{+}$is influenced by hydroxyl radicals and in turn regulates different enzymes involved in PCD (Demidchik et al., 2010). These findings suggest that maintenance of ionic homeostasis and proper $\mathrm{Na}^{+} / \mathrm{K}^{+}$ratios could be used to manipulate salt stress tolerance in crops (Huh etal., 2002; Teakle and Tyerman, 2010). For example, a recent study in rice demonstrated that BCL-2, an antiapoptotic protein, can regulate vacuolar processing enzymes (VPE), which play a crucial role in many PCD processes, by modulating ion fluxes. Overexpression of BCL-2 significantly reduces $\mathrm{NaCl}$-induced $\mathrm{K}^{+}$efflux, represses the expression of VPEs and thus alleviates PCD symptoms (Kim et al., 2014). A detailed model of the ion-specific signaling that triggers PCD under high $\mathrm{Na}^{+}$concentrations has been proposed by Shabala (2009). Another mode of modulating the stress and PCD responses is through cysteine protease inhibitors (cystatins). For instance, the overexpression of two Arabidopsis cystatins -
AtCYSa and AtCYSb - was shown to improve the tolerance not only to salt stress, but also to drought, cold and oxidation (Zhang et al., 2008).

Mitochondria play a pivotal role in salt-induced PCD in plants, especially in non-photosynthetic cells. The reason is that in these tissues mitochondria are the main ROS-producing compartment. The ROS burst in mitochondria may lead to a loss of outer membrane potential, which is an early marker for PCD in A. thaliana (Yao et al., 2004). Indeed, in tobacco protoplasts subjected to salt stress, the PCD program is mediated by ROS and depends on the opening of the mitochondrial permeability transition pores (PTP; Lin et al., 2006).

Since excessive ROS production switches on the PCD program and may jeopardize the survival of the plant, many of the responses towards abiotic stresses, including high salt concentrations, aim at minimizing the ROS threat. This is usually achieved by a very tight control of the antioxidant systems and upregulation of different antioxidants, both enzymatic and non-enzymatic. A good example is the halophytic shrub Prosopis strombulifera which after treatment with $\mathrm{Na}_{2} \mathrm{SO}_{4}$ boosts antioxidant activities, the synthesis of flavonoid compounds and increases the carotenoid/chlorophyll ratio (Reginato et al., 2014). Another mechanism to keep ROS levels under control, when subjected to salt stress, is the accumulation of compatible solutes. These organic osmolytes are needed to keep proper osmotic potential in stressed tissues but contribute also by alleviating oxidative stress (Liu et al., 2011; Duan et al., 2012). Interestingly, recent experiments performed with barley and wheat demonstrated that the rise in compatible solute concentrations provides cross-tolerance also to UV-B stress (Puniran-Hartley et al., 2014). Thus, despite being metabolically expensive in terms of required energy and carbon input, the salt-induced de novo synthesis of compatible solutes may serve multiple purposes and improve the chances of survival in hostile environments which pose a combination of abiotic challenges. The integrity of antioxidant systems is of vital importance for seeds as well. Their ability to germinate depends on the ROS status and a compromised antioxidant machinery, especially in combination with abiotic stresses, may significantly reduce germination efficiency. Such is the case in A. thaliana seeds which lack the cytosolic antioxidant ASCORBATE PEROXIDASE 6 when subjected to salt and heat stress (Chen et al., 2014).

\section{EXTREME TEMPERATURE-INDUCED PCD}

High temperatures significantly affect plant growth and development by triggering massive metabolic, physiological, and genetic reprogramming. Like other abiotic stress factors, heat shock is known to induce PCD (Vacca et al., 2004). Tobacco cells treated with high temperatures produce drastically larger quantities of ROS. These are a prerequisite for a successful PCD since addition of the antioxidants ascorbate or superoxide dismutase (SOD) to the cultures supports cell survival. Moreover, the authors show that both $\mathrm{H}_{2} \mathrm{O}_{2}$ and $\mathrm{O}_{2}^{\bullet-}$ are required and the absence of either of them compromises the PCD process. Mitochondria also play an important role in these conditions. They release functionally active cytochrome $\mathrm{c}$ in a ROS-dependent manner, which contributes to the activation of caspase-like proteases in the cytosol that execute the PCD program (Vacca et al., 2006). A newer study demonstrates 
that PCD is triggered only when the temperature rises above a specific threshold which is associated with metabolic changes that are considerably different to those in response to less intensive stimuli (Marsoni et al., 2010). For example, only in severe heat shocktreated cells is a down regulation of antioxidant proteins observed. This in turn leads to the perturbation of the redox homeostasis and plays a role in the PCD events. When subjected to shorter or less intensive heat stimuli plants can become primed and thus more resistant to subsequent stressful events. This enhanced thermotolerance is achieved by an improved antioxidant capacity, which in wheat seedlings is based on upregulated expression and higher activities of SODs, GR, and peroxidases (Wang et al., 2014) and once again confirms the importance of ROS homeostasis for plant performance under these conditions. An interesting fact is that proline, which acts as a compatible solute, ROS detoxifier and regulator of the redox balance (Szabados and Savoure, 2010), is inhibitory to Arabidopsis seedlings during heat stress ( $\mathrm{Lv}$ et al., 2011). This is in contrast to the role of proline for other types of stresses, especially salt/osmotic stress, where it has a protective role (Verbruggen and Hermans, 2008). These facts support the notion that every type of abiotic influence triggers a specific sequence of adaptive reactions.

An important detail is that the type and localization of ROS may influence the execution of the PCD program that follows. Recently it was observed that the exogenous application of the unspecific antioxidants ascorbate and glutathione to heat-treated A. thaliana cells actually favors the initiation of PCD, probably because cellular stress levels are reduced and the uncontrolled necrotic death is avoided. In contrast, treatment with catalase, which is specific only for $\mathrm{H}_{2} \mathrm{O}_{2}$, temporarily suppresses $\mathrm{PCD}$. The authors hypothesize that it is the $\mathrm{H}_{2} \mathrm{O}_{2}$ which may function as the PCD-inducing mobile signal, while the other types of ROS and the products of their activity serve as positive or negative regulators of the components of the PCD machinery (Doyle and McCabe, 2010).

It has been proposed that heat shock transcription factors (HSFs), which are central to the coordinated expression of heat shock proteins (HSPs) and other stress-related genes, have an important role in the ROS-mediated response to heat stress because they may function as ROS-sensitive sensors (Miller and Mittler, 2006). Both, the HSF and HSP genes are highly induced by ROS (Gechev et al., 2005; Piterkova et al., 2013). Lack of HSFA2 causes accumulation of higher ROS levels, more severe mitochondrial dysfunction and a lower survival rate due to increased PCD (Zhang et al., 2009a). In rice, overexpression of the mitochondrial HSP mtHSP70 may suppress the PCD response at elevated temperatures and after $\mathrm{H}_{2} \mathrm{O}_{2}$ treatment by maintaining the mitochondrial transmembrane potential $(\Delta \Psi \mathrm{m})$ and reducing ROS amplification (Qi et al., 2011). Other components of the molecular machinery transducing the heat shock signal include the mitogen-activated protein kinase 6 (MPK6) and $\gamma \mathrm{VPE}(\mathrm{Li}$ et al., 2012). According to this study, the cascade that is triggered at elevated temperatures starts with the accumulation of ROS and an increase of the cytosolic $\mathrm{Ca}^{2+}$ concentration. Calcium in turn is bound by a form of the ubiquitous second messenger calmodulin (CaM3) which leads to the activation of MPK6. Finally, MPK6 upregulates $\gamma$ VPE expression and $\gamma$ VPE precursors are targeted to the vacuole, where they are activated to process a number of vacuolar hydrolases and proteases associated with PCD.

Among the major sites of ROS production during heat shock is the photosynthetic apparatus. As a consequence of high temperature the photosystem II complexes (PSII) may be severely damaged due to cofactor dissociation. This has numerous effects, one of which is the formation of ROS (Mathur et al., 2014). Elevated concentrations of $\mathrm{H}_{2} \mathrm{O}_{2}$ may also be generated in peroxisomes due to photorespiratory activity which is significantly accelerated at elevated temperatures. The reason is the reduction of the relative specificity of ribulose-1,5-bisphosphate carboxylase/oxygenase ( $\mathrm{RuBisCO}$ ) for $\mathrm{CO}_{2}$ compared to $\mathrm{O}_{2}$ and the lower relative solubility of $\mathrm{CO}_{2}$ than $\mathrm{O}_{2}$ (Jordan and Ogren, 1984). However, the shift of $\mathrm{H}_{2} \mathrm{O}_{2}$ production from chloroplasts to peroxisomes due to photorespiration can be regarded as less dangerous since peroxisomes are better suited to cope with the $\mathrm{H}_{2} \mathrm{O}_{2}$ load mainly due to the abundance of the reductant-independent enzyme catalase (Wingler et al., 2000).

Low temperature (both chilling and freezing) on its own can also induce PCD in plants (Koukalova et al., 1997; Lyubushkina et al., 2014). Tobacco BY-2 suspension cells progressively develop characteristic features of PCD, including DNA condensation and fragmentation (laddering), after exposure to $5-6^{\circ} \mathrm{C}$ for two to 5 weeks (Koukalova et al., 1997). Interestingly, $11 \%$ of the cells did not die even after prolonged incubation at low temperature. Winter wheat (Triticum aestivum L.) cell cultures exposed to freezing treatment $\left(-8^{\circ} \mathrm{C}\right)$ undergo PCD accompanied by ROS accumulation, DNA fragmentation, and the release of cytochrome c from mitochondria into the cytosol (Lyubushkina et al., 2014). LESION SIMULATING DISEASE RESISTANCE 1 (LSD1) is a plant-specific negative regulator of PCD and its mutation causes ROS accumulation and runaway cell death (Jabs et al., 1996; Dietrich et al., 1997). LSD1 interacts with catalases in A. thaliana to keep ROS under control and loss of its function renders plants more susceptible to low temperature-induced cell death (Huang et al., 2010; Li et al., 2013).

Low temperature is particularly damaging when combined with elevated light intensities. During such conditions, the photosynthetic electron transport chains are overreduced, there is increased generation of ROS, and the antioxidant system cannot cope with it. As a result, photoinhibition or/and cell death occurs (Murata et al., 2007).

\section{UV LIGHT-INDUCED PCD}

The UV spectrum comprises three ranges of different wavelengths: UV-A (315-390 nm), UV-B (280-315 nm) and UV-C (below $280 \mathrm{~nm})$. Of these, UV-C is often used as a reliable trigger of PCD in scientific studies (Gao et al., 2008b) despite the fact that in natural conditions UV-C is absorbed by the ozone layer in the stratosphere and is therefore of little physiological relevance. UV-B exposure, in turn, has been widely considered as a potent stressor of plants in the past, but in the last years this concept has been reconsidered (Hideg et al., 2013) since many studies failed to demonstrate direct evidence for UV-B provoked stress in terrestrial ecosystems (Ballare et al., 2011). It was proposed that low, ecologically relevant UV-B doses induce so called "eustress," a condition 
that primes the plant for future oxidative pressure but does not impede growth and development per se, while high UV-B intensity leads to a state of "distress" which is associated with a ROS burst and may eventually result in PCD (Hideg et al., 2013). In experimental conditions the UV-B irradiation that is used is usually strong enough to overload the antioxidant capacities of the cells and cause oxidative stress.

Strong UV light has been shown to be deleterious to both animals and plants. In animals it causes apoptosis (Kulms and Schwarz, 2000) while in plants it leads to apoptotic-like symptoms like DNA laddering and fragmentation of the nucleus (Danon and Gallois, 1998). This abiotic cue leads to a sharp rise in $\mathrm{O}_{2}^{\bullet-}$ concentrations in chloroplasts due to $\mathrm{e}^{-}$excitation by energy transition in different photosensitizers (Hideg et al., 2002). The plastidic SODs can transform $\mathrm{O}_{2}^{\bullet-}$ to $\mathrm{H}_{2} \mathrm{O}_{2}$ which is another consequence of UV stress. In Rosa X damascena (the Damask rose) the peak of $\mathrm{H}_{2} \mathrm{O}_{2}$ accumulation is 60-90 min after irradiation (Murphy and Huerta, 1990). Recently, it was shown that in UV-B irradiated tobacco leaves the antioxidant activities targeting $\mathrm{H}_{2} \mathrm{O}_{2}$ are the most activated (Majer et al., 2014). This suggests that $\mathrm{H}_{2} \mathrm{O}_{2}$ scavenging would be crucial for survival in such conditions. Interestingly, it was shown by experiments with fluorescent sensors of different ROS forms that the relative portion of ${ }^{1} \mathrm{O}_{2}$ formed as a result of UV treatment is low in comparison to the other ROS (Hideg et al., 2002). To prevent PCD, high UV-B doses trigger a defense program aiming to alleviate the symptoms of oxidative stress including synthesis of the stress hormones salicylic acid (SA), jasmonic acid (JA), and ethylene, upregulation of pathogenesisrelated proteins and genes participating in senescence processes (Bandurska etal., 2013). Stress avoidance and stress tolerance strategies induce morphological changes and adaptations of the metabolism to favor the accumulation of flavonoids in epidermal cells, lignin deposition in cell walls, and to reinforce the antioxidant system with both enzymatic (SOD, catalase, peroxidases) and non-enzymatic ROS scavengers (carotenoids, tocopherols, ascorbic acid, PAs, etc.; Ueda and Nakamura, 2011; Zhang et al., 2012).

Two independent UV-B response pathways were proposed to act in accordance to the UV-B fluence rate (Nawkar et al., 2013). The UV RESISTANCE LOCUS8 protein (UVR8), characterized as a major UV-B photoreceptor (Kliebenstein et al., 2002; Rizzini et al., 2011), mediates photomorphogenic adaptive responses to moderate levels of UV-B. To achieve this UVR8 interacts with the CONSTITUTIVE PHOTOMORPHOGENESIS 1 (COP1) protein and induces the TFs ELONGATED HYPOCOTYL (HY5) and HY5 HOMOLOG (HYH; Brown and Jenkins, 2008). In contrast, high fluence rates trigger a stress UVR8-independent pathway that includes a mitogen-activated protein kinase (MAPK) cascade involving the antagonistic action of MAP KINASE PHOSPHATASE 1 (MKP1) and the MAP-kinases MPK3 and MPK6 (Gonzalez Besteiro et al., 2011).

The LSD1 and ENHANCED DISEASE SUSCEPTIBILITY 1 (EDS1) proteins are antagonistic regulators of the acclimation to UV-C stress, since $l s d 1$ mutants are characterized by enhanced cell death after UV-C treatment, while eds1 plants manifest the opposite phenotype. They exert their function by controlling the processes that extinguish excessive energy and modulate
ROS homeostasis (Wituszynska et al., 2014). In mitochondria, which are affected by UV-C, a ROS burst leads to a decline in the $\Delta \Psi \mathrm{m}$. Other symptoms of the mitochondrial dysfunction include changes of their distribution and mobility (Gao et al., 2008b). The rise of ROS quantities and the damage to mitochondria are important for the normal completion of a PCD program as indicated by the fact that treatment with the antioxidant ascorbic acid or the inhibitor of the mitochondrial PTPs, i.e. cyclosporine, reduces the rate of PCD. In summary, ROS that mediate the signal for PCD after UV-C treatment mainly originate in mitochondria and chloroplasts as described above, which in normal physiological conditions are in close proximity to allow metabolic interchange (Logan and Leaver, 2000). Moreover, light is also necessary for this type of PCD to occur as well as caspase-like activities as demonstrated by the ability of caspase inhibitors to impede the process (Danon et al., 2004; Zhang et al., 2009b).

\section{HIGH LIGHT-INDUCED PCD}

Light with intensity higher than $1000 \mu \mathrm{mol}$ photons $\mathrm{m}^{-2} \mathrm{~s}^{-1}$ can be very damaging to plants and especially to chloroplasts (Szechynska-Hebda and Karpinski, 2013). In these conditions, leading to excess excitation energy (EEE), leaves are exposed to more energy than they can actually utilize in photosynthesis or dissipate without being harmed (Wilhelm and Selmar, 2011). The enzymatic processes of $\mathrm{CO}_{2}$ fixation are slowed, which is accompanied by the synthesis of higher than necessary concentrations of NADPH and ATP. The increase in reducing equivalents reduces the plastoquinone pool and/or inhibits the oxygen evolution complex responsible for the photolysis of water. As a result the PSII complexes are inactivated, a process known as photoinhibition, which goes hand in hand with photoreduction of molecular oxygen to ROS (Anderson et al., 1997). If the antioxidant systems fail to keep ROS propagation under control, growth retardation and PCD may occur (Mateo et al., 2004). Examples of the damage that ROS can cause in these conditions include the degradation of glutamine synthetase, phosphoglycolate phosphatase, and the large subunit of RuBisCO as well as the increased occurrence of carbonyl groups in stromal proteins (Stieger and Feller, 1997).

Plants react with a complex adaptive systemic acquired acclimation response (SAA) towards EEE. Recently it has been shown that SAA and PCD signals are regulated by stomatal conductance, photorespiration, ROS homeostasis, hormonal balance as well as local changes in the plasma membrane electric potential called photoelectrophysiological signaling (PEPS; Szechynska-Hebda et al., 2010). The propagation of EEE-induced PCD initiated by changes in the redox state of the chloroplasts is dependent on the activities of several regulatory genes like LSD1, EDS1, PHYTOALEXIN DEFICIENT 4 (PAD4) and ETHYLENE INSENSITIVE2 (EIN2), whose protein products function upstream of ROS production (Muhlenbock et al., 2008; Karpinski et al., 2013).

Plants with compromised antioxidant systems or proper composition of the photosynthetic machinery have been widely used to study the PCD responses triggered by massive ROS accumulation provoked by excessive light. For example, experiments with the Arabidopsis mutants vte1npq1, deficient in $\alpha$-tocopherol and zeaxanthin, and $c h 1$, lacking chlorophyll $b$, have demonstrated that 
the rise of the ${ }^{1} \mathrm{O}_{2}$ concentrations following high light treatment can directly lead to PCD due to the cytotoxicity of ${ }^{1} \mathrm{O}_{2}$ (Triantaphylides et al., 2008). Interestingly, the ch1 mutant can be rescued from this ${ }^{1} \mathrm{O}_{2}$-dependent PCD if subjected to mild light stress acclimation first (Ramel et al., 2013). However, in another mutant, npq1lut2, which is unable to produce the ${ }^{1} \mathrm{O}_{2}$ quenchers lutein and zeaxanthin, ${ }^{1} \mathrm{O}_{2}$ responses did not include PCD (Alboresi et al., 2011), suggesting that the identity of ${ }^{1} \mathrm{O}_{2}$-induced reactions under high light depends on the source of ${ }^{1} \mathrm{O}_{2}$ in the chloroplasts and the intensity of the signal. $\mathrm{H}_{2} \mathrm{O}_{2}$ has also been shown to initiate PCD in excessively light-stressed plants (Vandenabeele et al., 2003; Mullineaux et al., 2006).

\section{HEAVY METAL-INDUCED PCD}

It is well-known that high concentrations of heavy metal ions can stimulate a ROS burst (Dat et al., 2000; Cho and Seo, 2005). Evidence for this is the increased lipid peroxidation in plants subjected to heavy metal stress. For example, after treatment of Solanum nigrum with cadmium (Cd), malondialdehyde accumulates, indicating augmented oxidation of membrane lipids by ROS (Deng et al., 2010). One should also keep in mind that some heavy metals, like $\mathrm{Fe}$ and $\mathrm{Cu}$, may participate in the Haber-Weiss reaction which leads to the production of the hyper-active hydroxyl radical (HO ${ }^{\bullet-}$; Kehrer, 2000).

Many reports study PCD induced by different heavy metal ions. $\mathrm{Cd}$, for example, appears to trigger PCD by a pathway that involves the endoplasmatic reticulum (ER), in which unfolded proteins accumulate (Xu et al., 2013). This has been demonstrated in Nicotiana tabacum BY-2 cells in which markers for ER stress (NtBLP4 and $N t P D I$ ) were upregulated after exposure to $C d$, while chemical and protein (expression of the Arabidopsis AtBiP2 gene) chaperones can suppress this induction, as well as the induction of the PCD-related gene NtHsr203J. Ethylene, which is modulated by ROS formation, also participates in the reactions of plants to Cd stress since it stimulates the onset of PCD (Yakimova et al., 2006; Liu et al., 2008). It appears that the cellular response to Cd involves complex crosstalk between ROS, $\mathrm{NO}, \mathrm{Ca}^{2+}$ ions, and hormones. In a study with pea plants it was shown that one of the primary effects of $\mathrm{Cd}^{2+}$ treatment is actually depletion of cytosolic $\mathrm{Ca}^{2+}$ which negatively regulates components of the antioxidant system like SOD. This results in elevated $\mathrm{H}_{2} \mathrm{O}_{2}$ and $\mathrm{O}_{2}^{\bullet-}$ concentrations. On the other hand, the reduction of $\mathrm{Ca}^{2+}$ affects also NO production, leading to its depression. But the decrease in $\mathrm{NO}$ can in turn promote the accumulation of $\mathrm{O}_{2}^{\bullet-}$, further exacerbating the oxidative load. The lipid peroxidation in membranes caused by ROS turns on JA and ethylene mediated pathways (Rodriguez-Serrano et al., 2009). Many genes undergo expression changes in such conditions, including elements of MAPK cascades as well as enzymes involved in ethylene, $\mathrm{NO}$ and PA metabolism (Kovalchuk et al., 2005; Chmielowska-Bak et al., 2013). The relationship between $\mathrm{Cd}$ and oxidative stresses manifests also in experiments with Arabidopsis mutants which are characterized by tolerance to both of them. Such is the case for plants overexpressing an aldehyde dehydrogenase (ALDH3; Sunkar et al., 2003), mutants of a MAP-kinase (mpk6; Jin et al., 2013) and the atr lines which are less sensitive to $\mathrm{Cd}$ - and paraquat-induced oxidative stress (Radeva et al., 2010).
Aluminum (Al) is another highly toxic element which causes damage to both animals, including humans, and plants. Al negatively affects the soil-derived water and nutrient supply in plants by inhibiting the division and elongation of root tip cells (Samac and Tesfaye, 2003). ROS burst, mitochondrial dysfunction, and induction of PCD are considered to be the main symptoms of exposure to $\mathrm{Al}$ at the cellular level ( $\mathrm{Li}$ and Xing, 2010). The sequence of events in these conditions includes stimulation of ROS synthesis, for example by a dramatic upregulation of the $\mathrm{O}_{2}^{\bullet-}$ producer respiratory burst oxidase homolog (Rboh), opening of the mitochondrial PTP, reduced potential of the inner mitochondrial membrane, release of cytochrome $\mathrm{c}$ into the cytosol and finally an activation of the caspase-like 3 protease (Huang et al., 2014). Interestingly, the PCD features are relieved after the application of protease and human caspase inhibitors, which suggests involvement of caspase-like proteases in the cell death process. A similar cell death-suppression effect is observed after addition of antioxidants like catalase, ascorbic acid and its precursor L-galactonic acid- $\gamma$-lactone as well as compounds known to interact with and inhibit NADPH oxidases (Yakimova et al., 2007), which once again confirms the importance of ROS for Al-induced PCD. The mitochondrial enzyme alternative oxidase (AOX), which is specific for plants and serves to prevent over-reduction of the mitochondrial electron transport chain, is also involved in $\mathrm{Al}$ stress as demonstrated recently (Liu et al., 2014). According to this study, AOX1a upregulation is provoked by $\mathrm{Al}$-derived $\mathrm{O}_{2}^{--}$in the mitochondria and AOX1a in turn can mitigate the following PCD by maintaining proper mitochondrial functions.

Tungsten (W) is not as abundant as $\mathrm{Al}$ and $\mathrm{Cd}$, but its quantities can be augmented as a result of human activities. Like other heavy metals, $\mathrm{W}$ is also harmful, with a negative impact on plant growth caused by binding to and inactivation of molybdoenzymes and switching on PCD. The cell death initiated by high $\mathrm{W}$ concentrations has been studied in pea root cells and according to the results the mechanism involves the ER, similar to Cd (Adamakis et al., 2011). A possible explanation for the effect of the inhibitory role of $\mathrm{W}$ on molybdoenzymes and the activation of ROS-dependent PCD came from the observation that the $x d h 1$ mutant of $A$. thaliana, which is deficient for the molybdenum-containing enzyme xanthine dehydrogenase, accumulated xanthine and exhibited symptoms of premature senescence (Brychkova et al., 2008). Furthermore, the $x d h 1$ mutant subjected to darkness and subsequent re-exposure to light accumulated ROS and exhibited cell death to a larger extent than the wild type, an effect that could be attenuated by the addition of allantoin or allantoate, indicating that these metabolites protect cells from cellular damage by ROS (Brychkova etal., 2008).

Unlike the non-essential metals like $\mathrm{Al}, \mathrm{W}$, and $\mathrm{Cd}$ mentioned above, some other metallic elements, such as zinc $(\mathrm{Zn})$, are important micronutrients with an array of functions. Although Zn deficiency has many negative consequences to plants, including growth retardation and reduction of the efficiency of the antioxidant system (Sharma et al., 2004), accumulation of $\mathrm{Zn}$ is highly deleterious (Wang et al., 2009). The mechanisms of Zn toxicity have not been fully elucidated yet, but similar to other heavy metals the symptoms involve a ROS imbalance and ultimately 
may lead to PCD. In a study with Solanum nigrum roots it was demonstrated that $\mathrm{Zn}^{2+}$ initially boosts $\mathrm{NO}$ production and $\mathrm{NO}$ in turn negatively regulates components of the antioxidant system thereby increasing ROS concentrations and triggering PCD. The rise of NO was proven to be necessary for this $\mathrm{Zn}$-induced PCD since its inhibition prevented ROS accumulation and the subsequent cell death (Xu et al., 2010). Interestingly, Zn participates also in beneficial PCD processes throughout plant development. In Norway spruce (Picea abies) somatic embryos $\mathrm{Zn}$ manifests an anti-cell death effect and is contained (in physiological concentrations) within the proliferating cells, while those that need to be subjected to PCD are Zn-depleted (Helmersson et al., 2008). All these findings confirm that in the case of $\mathrm{Zn}$ the dose makes the poison and disruption of its homeostasis in either direction depletion or accumulation - can have dramatic consequences to plants.

\section{FLOODING/LOW OXYGEN-INDUCED PCD}

Flooding represents a global problem which seriously diminishes crop yield. It has been estimated that nowadays more than 17 million $\mathrm{km}^{2}$ of arable land are prone to flooding and in certain areas the risk of flooding may further increase in the future (Shabala et al., 2014). The main problem to plants in these conditions is the significantly reduced availability of molecular oxygen which causes hypo- or anoxia. To alleviate the symptoms related to hypo/anoxia, plants resort to a defense strategy which involves the formation of specific air channels in the submerged tissues called aerenchyma. These interconnected cellular spaces facilitate gas diffusion and reduce the metabolic requirements of the flooded organs (Lenochova et al., 2009). Aerenchyma is formed after cells are selectively eliminated by a PCD process that shares some similarities with apoptosis and cytoplasmic cell death in animals (Gunawardena et al., 2001).

Numerous lines of evidence support the notion that ethylene and ROS are both integral parts of the mechanism of aerenchyma development. For example, Steffens et al. (2011) demonstrated that exogenous application of $\mathrm{H}_{2} \mathrm{O}_{2}$ stimulates lysigenous aerenchyma emergence in rice stems. Moreover, one of the highly upregulated genes during waterlogging in maize is Rboh, which, as mentioned earlier, is a major ROS producer (Rajhi etal., 2011). In addition, accompanying mitochondrial dysfunction and the accumulation of metal ions during flooding also increase ROS concentration (Shabala et al., 2014). On the other hand, it is long known that ethylene synthesis is enhanced in a low-oxygen environment and subsequently ethylene triggers PCD (He et al., 1996a,b). In a recent study it was shown that treatment of wheat seedlings with the precursor of ethylene, i.e., 1aminocyclopropanecarboxylic acid (ACC), promotes aerenchyma formation similar to $\mathrm{H}_{2} \mathrm{O}_{2}$ but the addition of the NADPH oxidase inhibitor diphenyleneiodonium chloride (DPI) suppresses the effect of ACC (Yamauchi et al., 2014). Applying DPI alone prevents the spread of submergence-dependent aerenchyma formation (Parlanti et al., 2011). These findings support the model that ROS are essential for aerenchyma development and participate in the transduction of an ethylene signal from which they act downstream. A similar mechanism involving ethylene and ROS operates in epidermal cells which need to undergo PCD in order to allow the emergence of adventitious roots in rice as a response to flooding (Steffens et al., 2012).

As in other cases of abiotic stress-induced PCD, the reactive nitrogen species (RNS) NO may also play a role during exposure to low oxygen levels. NO is mainly produced in mitochondria, mostly by the reduction of nitrite by the electron transport chain (Gupta and Igamberdiev, 2011). Importantly, a negative feedback loop between ROS, NO, and AOX was found to exist in mitochondria; NO is able to actually induce $A O X$ expression, probably to reduce the ROS and NO burden (Fu et al., 2010). Although this mechanism is supposed to keep ROS and NO concentrations under control, it may be overrun by ROS and NO from non-mitochondrial origin in which case PCD, caused by the ROS and NO accumulation, may occur (Gupta et al., 2012). During hypoxia another small moleculare, i.e., $\mathrm{H}_{2} \mathrm{~S}$, antagonizes $\mathrm{ROS}$ effects. In experiments with pea seedlings, treatment with $\mathrm{H}_{2} \mathrm{~S}$ significantly lowered root tip death by mitigating membrane damage by ROS and suppressing ethylene production. In contrast, the death of root tip cells was promoted after application of inhibitors of endogenous $\mathrm{H}_{2} \mathrm{~S}$ synthesis (Cheng et al., 2013).

\section{INTEGRATION OF PCD SIGNALS FROM THE ER, CHLOROPLASTS, AND MITOCHONDRIA}

As already described in the previous chapter, signals from different types of abiotic cues are often generated in specific cellular compartments like chloroplasts, mitochondria, or the ER. These organelles are prone to stress but in the same time possess mechanisms to process the information in accordance to the intensity of the stressor as well as the developmental stage and the previous experience of the plant. The local metabolic imbalances and ROS accumulation caused by the harmful abiotic conditions produce signals which are integrated and relayed to other parts of the cell, including the nucleus, and as a result cellular physiology and biochemistry are readjusted (Suzuki et al., 2012) to allow the plant to adapt. However, should the damage caused by the stressor be insurmountable, a PCD program may be induced.

\section{CHLOROPLASTS, MITOCHONDRIA, AND THEIR ROLE IN PCD}

As the organelles in which photosynthesis occurs, chloroplasts are extremely sensitive to abiotic factors, especially those related to light and UV irradiation. Due to the intensive energy fluxes, constant electron transport, and the demand for reducing power they are among the major sites of ROS production in plant cells (Baier and Dietz, 2005). Information of the current redox-status of these organelles, which reflects also the ROS concentrations, may be transmitted by monitoring the state of the plastoquinone, ascorbate, and glutathione pools (Foyer and Noctor, 2009). Chloroplasts, as well as mitochondria, send signals to the nucleus, a process known as retrograde signaling (Suzuki et al., 2012), and in this way they may influence the expression of numerous genes in accordance with their redox condition, including triggers of PCD.

A well-studied example is the ability of ${ }^{1} \mathrm{O}_{2}$ to initiate suicide responses. ${ }^{1} \mathrm{O}_{2}$ is generated mainly by excited triplet state chlorophyll, photosensitizers like protochlorophyllide in the presence of light or in the PSII light harvesting complex when the electron transport chain is over-reduced as a result of stress (Apel 
and Hirt, 2004). To achieve ${ }^{1} \mathrm{O}_{2}$ accumulation, scientists have often applied a dark-to-light shift of the conditional flu mutant of Arabidopsis, which retains high levels of the chlorophyll precursor and photosensitizer protochlorophyllide (op den Camp et al., 2003; Laloi etal., 2007). Work with this mutant has provided evidence that ${ }^{1} \mathrm{O}_{2}$ does not induce PCD merely due to its cytotoxic effects, but actually switches on a genetically controlled program driven by factors like EXECUTER1 and EXECUTER2 (Lee et al., 2007). The light-dependent release of ${ }^{1} \mathrm{O}_{2}$ alone cannot provoke cell death, but needs in addition the blue light-specific photoreceptor cryptochrome (Danon et al., 2006). Suppressor mutants of the flu mutation called singlet oxygen-linked death activators (soldat), in which the ${ }^{1} \mathrm{O}_{2}$-induced cell death is eliminated, have also been found (Coll et al., 2009; Meskauskiene et al., 2009). $\mathrm{A}^{1} \mathrm{O}_{2}$-provoked PCD is also observed in the oep 16 mutant, which is defective in NADPH:protochlorophyllide oxidoreductase A import and accumulates protochlorophyllide (Samol et al., 2011). Another way of ${ }^{1} \mathrm{O}_{2}$ accumulation is observed in the previously mentioned chlorina (ch1) mutant, which is deficient in chlorophyll $b$ (Ramel et al., 2013). The ${ }^{1} \mathrm{O}_{2}$-induced gene expression in chl resembles flu. Moderately elevated light intensities can repress the jasmonate pathway and induce acclimation, while jasmonate signaling is strongly induced by high light intensities that trigger PCD (Ramel et al., 2013).

Another ROS species, i.e., hydrogen peroxide, appears to antagonize the effects of ${ }^{1} \mathrm{O}_{2}$ in chloroplasts (Laloi et al., 2007) which supports the idea that the identity of the ROS signal is of primary importance for the ensuing outcome. In another study it was found that in Arabidopsis cell suspension cultures only the treatment with the ${ }^{1} \mathrm{O}_{2}$-producing chemical Rose Bengal (RB), but not with $\mathrm{H}_{2} \mathrm{O}_{2}$, triggers $\mathrm{PCD}$, again confirming the importance of the nature of the ROS signal (Gutierrez et al., 2014). Moreover, these authors show that the ${ }^{1} \mathrm{O}_{2}$-mediated cell death program requires functional chloroplasts since dark-incubated cells, which lack them, had the PCD response suppressed. Arabidopsis cell suspension cultures were used to investigate also the apoptotic-like PCD (AL-PCD) that follows a heat shock treatment at $55^{\circ} \mathrm{C}$ (Doyle et al., 2010). However, in this case the presence of viable chloroplasts seemed to reduce the occurrence of AL-PCD at the expense of necrotic cell death. In addition, treatment of chloroplast-containing cells with antioxidants increased the proportion of AL-PCD and decreased the number of necrotic cells which demonstrates the crucial role of plastid-originated ROS for PCD regulation. A possible explanation of these observations could be that cultures containing chloroplasts, which are major ROS producing sites, more easily lose control of their ROS metabolism after the heat shock, which prevents the genetically organized PCD process and leads to the more chaotic necrosis instead.

As mentioned earlier, mitochondria are active participants in abiotic stress-induced PCD. The decrease of $\Delta \Psi \mathrm{m}$, most often accompanied by the release of cytochrome $c$, are common early markers of plant PCD as they are in animals (Yao et al., 2004). This in turn results in the oxidation of a number of macromolecules, including lipids. The oxidation of cardiolipin negatively influences the strength of cytochrome $\mathrm{c}$ binding to the inner mitochondrial membrane and leads to its diffusion into the intramembrane space. At the same time, the oxidative stress causes permeabilization of the transition pores in the outer membrane thus letting cyt $\mathrm{c}$ pass into the cytosol (Ott et al., 2007). In plants there is no evidence that cyt c can directly activate PCD (Reape and McCabe, 2008), but it appears to be one of the prerequisites, together with ROS (Vacca et al., 2006). It has been proposed that when the PTP are open and cyt $\mathrm{c}$ is dissipated, even more ROS are generated in the mitochondrial electron transport chain (mtETC), which forms a positive feedback loop to amplify the original signal (Reape and McCabe, 2008). Therefore, the cyt c leakage seems to mark the "point of no return" after which PCD execution is inevitable. Similarly to chloroplasts, mitochondria can also produce retrograde signals to notify the nucleus of their current stress status. An example is the TF ANAC013 in Arabidopsis which was recently described to convey information about mitochondrial dysfunction to the nucleus and to lead to increased oxidative stress tolerance. Interestingly, ANAC013 is located in the ER under non-stress conditions, which demonstrates the tight physical and functional interactions between the ER and the mitochondria (De Clercq et al., 2013).

\section{THE ER AND ITS ROLE IN PCD}

The ER is an organelle with essential functions for protein sorting, post-translational modifications (such as $N$-glycosylation), and proper folding (Csala et al., 2006). In case these processes are impaired due to detrimental environmental factors, a specific phenomenon termed as "ER stress" can ensue, which is characterized by the accumulation of misfolded proteins (Cai et al., 2014). Adaptation to ER stress is achieved through the so called unfolded protein response (UPR), in the course of which signals from the ER are sent to the nucleus, which in turn increases the protein folding capacity of the cell (Watanabe and Lam, 2009). TFs like CabZIP1 from pepper and AtbZIP28 and AtbZIP60 from Arabidopsis, which participate in the transduction of the UPR, are already known to contribute to resistance to abiotic stressors like heat, drought, and high salinity (Fujita et al., 2007; Gao et al., 2008a; Moreno and Orellana, 2011). However, when the ER stress signal is too intense, a cell death program is triggered instead (Boyce and Yuan, 2006). Recently, the Arabidopsis membrane-associated TF ANAC089, which relocates to the nucleus under severe ER stress, was identified as one of the controllers that cause PCD in such conditions (Yang et al., 2014).

Similar to other varieties of stress-induced PCD, ROS take part in the ER-PCD as well, mostly by provoking the mobilization of $\mathrm{Ca}^{2+}$ from the ER to mitochondria, where $\mathrm{Ca}^{2+}$ opens the mitochondrial PTPs (Williams et al., 2014). This proves once more that the ER and mitochondria can exchange information and integrate common PCD signals. As in other cases of PCD triggered by adverse conditions, the VPE can be implicated in the execution of the cell death program during severe ER stress. In soybean (Glycine max), for example, VPE may be switched on by the cooperative action of two NAC TFs, i.e., GmNAC30 and GmNAC81, which together integrate both ER- and osmotic stress-induced cell death responses (Mendes et al., 2013).

Among the numerous PCD regulators in animals, much attention has been paid on the BCL2-associated X protein (BAX), as a pro-apoptotic factor, and on BAX inhibitor-1 (BI-1), as an antiapoptotic protein (Isbat et al., 2009). No BAX homologs have 
been reported in plants, while $B I-1$ is well conserved also in the plant kingdom. Its protein product is resident in the ER and takes an important part in the regulation of cell death (Watanabe and Lam, 2009). BI-1 is upregulated in response to many adverse abiotic stimuli and contributes to plant tolerance to a variety of stress factors (Watanabe and Lam, 2006; Isbat et al., 2009). Interestingly, the overexpression of Arabidopsis BI-1 (AtBI-1) efficiently prevents PCD driven by the exogenous application of $\mathrm{H}_{2} \mathrm{O}_{2}$ or ectopic expression of mammalian BAX, but does not influence the accompanying ROS accumulation (Kawai-Yamada et al., 2004). On the other hand, some antioxidant enzymes like Fe-SOD, APX, and glutathione $S$-transferase (GST) were identified as BAX inhibitors in a genetic screen with yeast (Watanabe and Lam, 2009), which implies that ROS are important components of BAX-mediated cell death. These findings suggest that BI-1 acts downstream of ROS in the PCD pathways in plants.

It was recently reported that an NADPH-dependent cytochrome P450 oxidoreductase is able to interact with human BI- 1 and as a result the electron uncoupling between this P450 reductase and cytochrome $\mathrm{P} 4502 \mathrm{E} 1$, known to be a major source of ROS at the ER membrane, is reduced. This, in turn, leads to a decrease in ROS production that may lower the unfolded and misfolded protein accumulation in the ER (Ishikawa et al., 2011). However, whether such an adaptive mechanism, that alleviates ER stress by relaxation of the oxidative load, is operational in plants is currently unclear.

\section{INFLUENCE OF THE DEVELOPMENTAL STAGE ON THE SEVERITY OF OXIDATIVE STRESS DAMAGE AND SENESCENCE}

As mentioned in the Introduction and Figure 1, the outcome of ROS accumulation depends not only on their concentration and site of production, but also on other factors like previous stress experience and interaction with other signals. The developmental stage of a plant is also of prime importance for its ability to withstand adverse environmental conditions or initiate senescence. Ethylene can accelerate the leaf senescence symptoms in wildtype $A$. thaliana plants older than 17 days but no visible yellowing is observed in younger plants (Jing et al., 2002). This ethyleneinduced leaf senescence is regulated in part by the ONSET OF LEAF DEATH (OLD) genes (Jing et al., 2005). It has been demonstrated that from a certain age, the photosynthetic activity in chloroplasts is reduced, while the oxidative stress progressively increases (Munné-Bosch and Alegre, 2002), which further contributes to the aging process. This negative impact on the ROS balance is due to numerous metabolic alterations related to age, such as the reduction of the ascorbate levels and the activity of antioxidant enzymes (Khanna-Chopra, 2012). The age-dependence of the severity of abiotic stress was investigated in growing maize leaf cells (Kravchik and Bernstein, 2013). The authors show that the response to salinity is influenced by age since younger cells possess more potent ROS-scavenging mechanisms in comparison to their older counterparts. Similar results were reported in a study of the acclimation to water deficit (Sperdouli and Moustakas, 2014). Younger leaves of A. thaliana owned their better tolerance to moderate water deficit mainly through the increased protection from
ROS, which includes also more pronounced sugar accumulation, more stimulated photochemical quenching and higher levels of proline. In an experiment involving treatment of different squash cultivars with the potent oxidative stress inducer paraquat, Yoon et al. (2011) demonstrated that 14 out of 18 cultivars are characterized by lower levels of paraquat damage in younger leaves. The significance of the developmental stage for the tolerance is not only true for abiotic factors, but for biotic stressors as well, like in the case of tobacco leaves which were differentially susceptible to the metabolic products of Alternaria alternata (Jia et al., 2010).

\section{CONCLUSION}

Programmed cell death is a central process in plant development, but in addition is triggered by a diverse spectrum of abiotic (and biotic) stresses, as highlighted here. Although the molecular and biochemical mechanisms underlying abiotic stress-induced PCD are being unraveled, several important questions remain to be answered in the future, such as: Which of the genes, proteins and regulatory networks involved in developmental PCD are also recruited for abiotic stress-induced PCD? At which point do the upstream signaling pathways that activate developmental and stress-triggered PCD converge and to what extent determine (or restrict) developmental programs the entrance into abiotic stress-induced PCD? Which of these genes and pathways are conserved in the plant kingdom (crops included) and which of them are species-specific or restricted to particular taxonomic groups? How is abiotic stress-induced PCD integrated into whole-plant physiology and development (e.g., with respect to the initiation of new leaves after drought stress which may have caused damage and loss of older leaves)? Answering these and other important questions about the abiotic stress-induced ROS-dependent PCD can ultimately help to develop high-yielding and at the same time more resilient crop varieties.

\section{ACKNOWLEDGMENTS}

The authors thank Dr. M. Kostova for the artwork. TG acknowledges the financial support of the Swiss Enlargement Contribution in the framework of the Bulgarian-Swiss Research Programme (projects No. IZEBZ0_143003/1 from SNSF and DO2-1068 from the Ministry of Education, Youth, and Science of Bulgaria) and EU FP7 (MC-IEF grant No. 329816 Plant Survivor).

\section{REFERENCES}

Abogadallah, G. M. (2010). Antioxidative defense under salt stress. Plant Signal. Behav. 5, 369-374. doi: 10.4161/psb.5.4.10873

Adamakis, I. D., Panteris, E., and Eleftheriou, E. P. (2011). The fatal effect of tungsten on Pisum sativum L. root cells: indications for endoplasmic reticulum stress-induced programmed cell death. Planta 234, 21-34. doi: 10.1007/s00425011-1372-5

Affenzeller, M. J., Darehshouri, A., Andosch, A., Lutz, C., and LutzMeindl, U. (2009). Salt stress-induced cell death in the unicellular green alga Micrasterias denticulata. J. Exp. Bot. 60, 939-954. doi: 10.1093/jxb/ ern348

Alboresi, A., Dall'osto, L., Aprile, A., Carillo, P., Roncaglia, E., Cattivelli, L., et al. (2011). Reactive oxygen species and transcript analysis upon excess light treatment in wild-type Arabidopsis thaliana vs a photosensitive mutant lacking zeaxanthin and lutein. BMC Plant Biol. 11:62. doi: 10.1186/1471-2229-11-62

Anderson, J. M., Park, Y. I., and Chow, W. S. (1997). Photoinactivation and photoprotection of photosystem II in nature. Physiol. Plant. 100, 214-223. doi: 10.1034/j.1399-3054.1997.1000202.x 
Apel, K., and Hirt, H. (2004). Reactive oxygen species: metabolism, oxidative stress, and signal transduction. Annu. Rev. Plant Biol. 55, 373-399. doi: 10.1146/annurev.arplant.55.031903.141701

Atkinson, N. J., and Urwin, P. E. (2012). The interaction of plant biotic and abiotic stresses: from genes to the field. J. Exp. Bot. 63, 3523-3543. doi: 10.1093/jxb/ers100

Baena-Gonzalez, E., Rolland, F., Thevelein, J. M., and Sheen, J. (2007). A central integrator of transcription networks in plant stress and energy signalling. Nature 448, 938-942. doi: 10.1038/nature06069

Baier, M., and Dietz, K. J. (2005). Chloroplasts as source and target of cellular redox regulation: a discussion on chloroplast redox signals in the context of plant physiology. J. Exp. Bot. 56, 1449-1462. doi: 10.1093/jxb/eri161

Ballare, C. L., Caldwell, M. M., Flint, S. D., Robinson, S. A., and Bornman, J. F. (2011). Effects of solar ultraviolet radiation on terrestrial ecosystems. Patterns, mechanisms, and interactions with climate change. Photochem. Photobiol. Sci. 10, 226-241. doi: 10.1039/c0pp90035d

Bandurska, H., Niedziela, J., and Chadzinikolau, T. (2013). Separate and combined responses to water deficit and UV-B radiation. Plant Sci. 213, 98-105. doi: 10.1016/j.plantsci.2013.09.003

Begcy, K., Mariano, E. D., Mattiello, L., Nunes, A. V., Mazzafera, P., Maia, I. G. et al. (2011). An Arabidopsis mitochondrial uncoupling protein confers tolerance to drought and salt stress in transgenic tobacco plants. PLoS ONE 6:e23776. doi: 10.1371/journal.pone.0023776

Blanvillain, R., Young, B., Cai, Y. M., Hecht, V., Varoquaux, F., Delorme, V., et al (2011). The Arabidopsis peptide kiss of death is an inducer of programmed cell death. EMBO J. 30, 1173-1183. doi: 10.1038/emboj.2011.14

Bolouri-Moghaddam, M. R., Le Roy, K., Xiang, L., Rolland, F., and Van Den Ende, W. (2010). Sugar signalling and antioxidant network connections in plant cells. FEBS J. 277, 2022-2037. doi: 10.1111/j.1742-4658.2010.07633.x

Bostock, R. M., Pye, M. F., and Roubtsova, T. V. (2014). Predisposition in plant disease: exploiting the nexus in abiotic and biotic stress perception and response. Annu. Rev. Phytopathol. 52, 517-549. doi: 10.1146/annurev-phyto-081211172902

Boyce, M., and Yuan, J. (2006). Cellular response to endoplasmic reticulum stress: a matter of life or death. Cell Death. Differ. 13, 363-373. doi 10.1038/sj.cdd.4401817

Brown, B. A., and Jenkins, G. I. (2008). UV-B signaling pathways with different fluence-rate response profiles are distinguished in mature Arabidopsis leaf tissue by requirement for UVR8, HY5, and HYH. Plant Physiol. 146, 576-588. doi: $10.1104 /$ pp.107.108456

Brychkova, G., Alikulov, Z., Fluhr, R., and Sagi, M. (2008). A critical role for ureides in dark- and senescence-induced purine remobilization is unmasked in the Atxdh1 Arabidopsis mutant. Plant J. 54, 496-509. doi: 10.1111/j.1365313X.2008.03440.x

Cai, Y. M., Yu, J., and Gallois, P. (2014). Endoplasmic reticulum stressinduced PCD and caspase-like activities involved. Front. Plant Sci. 5:41. doi 10.3389/fpls.2014.00041

Chen, C., Letnik, I., Hacham, Y., Dobrev, P., Ben-Daniel, B. H., Vankova, R., et al. (2014). Ascorbate peroxidase 6 protects Arabidopsis thaliana desiccating and germinating seeds from stress and mediates crosstalk between ROS, ABA and auxin. Plant Physiol. 166, 370-383. doi: 10.1104/pp.114.245324

Cheng, W., Zhang, L., Jiao, C., Su, M., Yang, T., Zhou, L., et al. (2013). Hydrogen sulfide alleviates hypoxia-induced root tip death in Pisum sativum. Plant Physiol. Biochem. 70, 278-286. doi: 10.1016/j.plaphy.2013.05.042

Chmielowska-Bak, J., Lefevre, I., Lutts, S., and Deckert, J. (2013). Short term signaling responses in roots of young soybean seedlings exposed to cadmium stress. J. Plant Physiol. 170, 1585-1594. doi: 10.1016/j.jplph.2013.06.019

Cho, U. H., and Seo, N. H. (2005). Oxidative stress in Arabidopsis thaliana exposed to cadmium is due to hydrogen peroxide accumulation. Plant Sci. 168, 113-120. doi: 10.1016/j.plantsci.2004.07.021

Coll, N. S., Danon, A., Meurer, J., Cho, W. K., and Apel, K. (2009). Characterization of soldat8, a suppressor of singlet oxygen-induced cell death in Arabidopsis seedlings. Plant Cell Physiol. 50, 707-718. doi: 10.1093/pcp/pcp036

Cominelli, E., Conti, L., Tonelli, C., and Galbiati, M. (2013). Challenges and perspectives to improve crop drought and salinity tolerance. Nat. Biotechnol. 30, 355-361. doi: 10.1016/j.nbt.2012.11.001

Csala, M., Banhegyi, G., and Benedetti, A. (2006). Endoplasmic reticulum: a metabolic compartment. FEBS Lett. 580, 2160-2165. doi: 10.1016/j.febslet.2006.03.050
Danon, A., Coll, N. S., and Apel, K. (2006). Cryptochrome-1-dependent execution of programmed cell death induced by singlet oxygen in Arabidopsis thaliana. Proc. Natl. Acad. Sci. U.S.A. 103, 17036-17041. doi: 10.1073/pnas.0608139103

Danon, A., and Gallois, P. (1998). UV-C radiation induces apoptotic-like changes in Arabidopsis thaliana. FEBS Lett. 437, 131-136. doi: 10.1016/S00145793(98)01208-3

Danon, A., Rotari, V. I., Gordon, A., Mailhac, N., and Gallois, P. (2004). UltravioletC overexposure induces programmed cell death in Arabidopsis, which is mediated by caspase-like activities and which can be suppressed by caspase inhibitors, p35 and Defender against Apoptotic Death. J. Biol. Chem. 279, 779-787. doi: 10.1074/jbc.M304468200M304468200

Dat, J., Vandenabeele, S., Vranova, E., Van Montagu, M., Inze, D., and Van Breusegem, F. (2000). Dual action of the active oxygen species during plant stress responses. Cell Mol. Life Sci. 57, 779-795. doi: 10.1007/s000180050041

De Block, M., Verduyn, C., De Brouwer, D., and Cornelissen, M. (2005). Poly(ADPribose) polymerase in plants affects energy homeostasis, cell death and stress tolerance. Plant J. 41, 95-106. doi: 10.1111/j.1365-313X.2004.02277.x

De Clercq, I., Vermeirssen, V., Van Aken, O., Vandepoele, K., Murcha, M. W., Law, S. R., et al. (2013). The membrane-bound NAC transcription factor ANAC013 functions in mitochondrial retrograde regulation of the oxidative stress response in Arabidopsis. Plant Cell 25, 3472-3490. doi: 10.1105/tpc.113.117168

Demidchik, V., Cuin, T. A., Svistunenko, D., Smith, S. J., Miller, A. J., Shabala, S., et al. (2010). Arabidopsis root K+-efflux conductance activated by hydroxyl radicals: single-channel properties, genetic basis and involvement in stress-induced cell death. J. Cell Sci. 123, 1468-1479. doi: 10.1242/jcs.064352

Deng, X., Xia, Y., Hu, W., Zhang, H., and Shen, Z. (2010). Cadmium-induced oxidative damage and protective effects of $N$-acetyl- $L$-cysteine against cadmium toxicity in Solanum nigrum L. J. Hazard. Mater. 180, 722-729. doi: 10.1016/j.jhazmat.2010.04.099

De Storme, N., and Geelen, D. (2014). The impact of environmental stress on male reproductive development in plants: biological processes and molecular mechanisms. Plant Cell Environ. 37, 1-18. doi: 10.1111/pce.12142

Dietrich, R. A., Richberg, M. H., Schmidt, R., Dean, C., and Dangl, J. L. (1997). A novel zinc finger protein is encoded by the Arabidopsis LSD1 gene and functions as a negative regulator of plant cell death. Cell 88, 685-694. doi: 10.1016/S00928674(00)81911-X

Doyle, S. M., Diamond, M., and Mccabe, P. F. (2010). Chloroplast and reactive oxygen species involvement in apoptotic-like programmed cell death in Arabidopsis suspension cultures. J. Exp. Bot. 61, 473-482. doi: 10.1093/jxb/erp320

Doyle, S. M., and McCabe, P. F. (2010). Type and cellular location of reactive oxygen species determine activation or suppression of programmed cell death in Arabidopsis suspension cultures. Plant Signal. Behav. 5, 467-468. doi: 10.4161/psb.5.4.11399

Duan, J., Zhang, M., Zhang, H., Xiong, H., Liu, P., Ali, J., et al. (2012). OsMIOX, a myo-inositol oxygenase gene, improves drought tolerance through scavenging of reactive oxygen species in rice (Oryza sativa L.). Plant Sci. 196, 143-151. doi: 10.1016/j.plantsci.2012.08.003

Duan, Y., Zhang, W., Li, B., Wang, Y., Li, K., Sodmergen, et al. (2010). An endoplasmic reticulum response pathway mediates programmed cell death of root tip induced by water stress in Arabidopsis. New Phytol. 186, 681-695. doi: 10.1111/j.1469-8137.2010.03207.x

Farrant, J., Brandt, W. F., and Lidsey, G. G. (2007). An ovewview of the mechanisms of dessication tolerance in selected angiosperm resurrection plants. Plant Stress $1,72-84$.

Foyer, C. H., and Noctor, G. (2009). Redox regulation in photosynthetic organisms: signaling, acclimation, and practical implications. Antioxid. Redox. Signal. 11, 861-905. doi: 10.1089/ars.2008.2177

Fu, L. J., Shi, K., Gu, M., Zhou, Y. H., Dong, D. K., Liang, W. S., et al. (2010). Systemic induction and role of mitochondrial alternative oxidase and nitric oxide in a compatible tomato-tobacco mosaic virus interaction. Mol. Plant Microbe Interact. 23, 39-48. doi: 10.1094/MPMI-23-1-0039

Fujita, M., Mizukado, S., Fujita, Y., Ichikawa, T., Nakazawa, M., Seki, M., et al. (2007). Identification of stress-tolerance-related transcription-factor genes via mini-scale Full-length cDNA Over-eXpressor (FOX) gene hunting system. Biochem. Biophys. Res. Commun. 364, 250-257. doi: 10.1016/j.bbrc.2007.09.124

Gadjev, I., Stone, J. M., and Gechev, T. S. (2008). Programmed cell death in plants: new insights into redox regulation and the role of hydrogen peroxide. Int. Rev. Cell Mol. Biol. 270, 87-144. doi: 10.1016/S1937-6448(08)01403-2 
Gao, H., Brandizzi, F., Benning, C., and Larkin, R. M. (2008a). A membranetethered transcription factor defines a branch of the heat stress response in Arabidopsis thaliana. Proc. Natl. Acad. Sci. U.S.A. 105, 16398-16403. doi: 10.1073/pnas.0808463105

Gao, C., Xing, D., Li, L., and Zhang, L. (2008b). Implication of reactive oxygen species and mitochondrial dysfunction in the early stages of plant programmed cell death induced by ultraviolet-C overexposure. Planta 227, 755-767. doi: 10.1007/s00425-007-0654-4

Gechev, T. S., Dinakar, C., Benina, M., Toneva, V., and Bartels, D. (2012). Molecular mechanisms of desiccation tolerance in resurrection plants. Cell Mol. Life Sci. 69 , 3175-3186. doi: 10.1007/s00018-012-1088-0

Gechev, T. S., and Hille, J. (2005). Hydrogen peroxide as a signal controlling plant programmed cell death. J. Cell Biol. 168, 17-20. doi: 10.1083/jcb.200409170

Gechev, T., Minkov, I., and Hille, J. (2005). Hydrogen peroxide-induced cell death in Arabidopsis: transcriptional and mutant analysis reveals a role of an oxoglutaratedependent dioxygenase gene in the cell death process. IUBMB Life 57, 181-188. doi: 10.1080/15216540500090793

Gechev, T. S., Van Breusegem, F., Stone, J. M., Denev, I., and Laloi, C. (2006). Reactive oxygen species as signals that modulate plant stress responses and programmed cell death. Bioessays 28, 1091-1101. doi: 10.1002/bies.20493

Gill, S. S., and Tuteja, N. (2010). Reactive oxygen species and antioxidant machinery in abiotic stress tolerance in crop plants. Plant Physiol. Biochem. 48, 909-930. doi: 10.1016/j.plaphy.2010.08.016

Godfray, H. C., Beddington, J. R., Crute, I. R., Haddad, L., Lawrence, D., Muir, J. F., et al. (2010). Food security: the challenge of feeding 9 billion people. Science 327 812-818. doi: 10.1126/science. 1185383

Gonzalez Besteiro, M. A., Bartels, S., Albert, A., and Ulm, R. (2011). Arabidopsis MAP kinase phosphatase 1 and its target MAP kinases 3 and 6 antagonistically determine UV-B stress tolerance, independent of the UVR8 photoreceptor pathway. Plant J. 68, 727-737. doi: 10.1111/j.1365-313X.2011.04725.x

Gunawardena, A. H., Pearce, D. M., Jackson, M. B., Hawes, C. R., and Evans, D. E. (2001). Characterisation of programmed cell death during aerenchyma formation induced by ethylene or hypoxia in roots of maize (Zea mays L.). Planta 212, 205-214. doi: 10.1007/s004250000381

Gupta, K. J., and Igamberdiev, A. U. (2011). The anoxic plant mitochondrion as a nitrite: NO reductase. Mitochondrion 11, 537-543. doi 10.1016/j.mito.2011.03.005

Gupta, K. J., Igamberdiev, A. U., and Mur, L. A. (2012). NO and ROS homeostasis in mitochondria: a central role for alternative oxidase. New Phytol. 195, 1-3. doi: 10.1111/j.1469-8137.2012.04189.x

Gutierrez, J., Gonzalez-Perez, S., Garcia-Garcia, F., Daly, C. T., Lorenzo, O., Revuelta, J. L., et al. (2014). Programmed cell death activated by Rose Bengal in Arabidopsis thaliana cell suspension cultures requires functional chloroplasts. J. Exp. Bot. 65, 3081-3095. doi: 10.1093/jxb/eru151

He, C. J., Finlayson, S. A., Drew, M. C., Jordan, W. R., and Morgan, P. W. (1996a) Ethylene biosynthesis during aerenchyma formation in roots of maize subjected to mechanical impedance and hypoxia. Plant Physiol. 112, 1679-1685. doi: 10.1104/pp.112.4.1679

He, C. J., Jin, J. P., Cobb, B. G., Morgan, P. W., and Drew, M. C. (1996b). Transduction of an ethylene signal is required for cell death and lysis in the root cortex of maize during aerenchyma formation induced by hypoxia. Plant Physiol. 111, 699-699.

He, R., Drury, G. E., Rotari, V. I., Gordon, A., Willer, M., Farzaneh, T., et al. (2008). Metacaspase- 8 modulates programmed cell death induced by ultraviolet light and H2O2 in Arabidopsis. J. Biol. Chem. 283, 774-783. doi: 10.1074/jbc.M704185200

Helmersson, A., Von Arnold, S., and Bozhkov, P. V. (2008). The level of free intracellular zinc mediates programmed cell death/cell survival decisions in plant embryos. Plant Physiol. 147, 1158-1167. doi: 10.1104/pp.108.122598

Hideg, E., Barta, C., Kalai, T., Vass, I., Hideg, K., and Asada, K. (2002). Detection of singlet oxygen and superoxide with fluorescent sensors in leaves under stress by photoinhibition or UV radiation. Plant Cell Physiol. 43, 1154-1164. doi: $10.1093 / \mathrm{pcp} / \mathrm{pcf} 145$

Hideg, E., Jansen, M. A., and Strid, A. (2013). UV-B exposure, ROS, and stress: inseparable companions or loosely linked associates? Trends Plant Sci. 18, 107115. doi: 10.1016/j.tplants.2012.09.003

Hirayama, T., and Shinozaki, K. (2010). Research on plant abiotic stress responses in the post-genome era: past, present and future. Plant J. 61, 1041-1052. doi: 10.1111/j.1365-313X.2010.04124.x

Hoepflinger, M. C., Reitsamer, J., Geretschlaeger, A. M., Mehlmer, N., and Tenhaken, R. (2013). The effect of translationally controlled tumour protein (TCTP) on programmed cell death in plants. BMC Plant Biol. 13:135. doi: 10.1186/14712229-13-135

Huang, W., Yang, X., Yao, S., Lwinoo, T., He, H., Wang, A., et al. (2014). Reactive oxygen species burst induced by aluminum stress triggers mitochondria-dependent programmed cell death in peanut root tip cells. Plant Physiol. Biochem. 82, 76-84. doi: 10.1016/j.plaphy.2014.03.037

Huang, X., Li, Y., Zhang, X., Zuo, J., and Yang, S. (2010). The Arabidopsis LSD1 gene plays an important role in the regulation of low temperature-dependent cell death. New Phytol. 187, 301-312. doi: 10.1111/j.1469-8137.2010.03275.x

Huh, G. H., Damsz, B., Matsumoto, T. K., Reddy, M. P., Rus, A. M., Ibeas, J. I., et al. (2002). Salt causes ion disequilibrium-induced programmed cell death in yeast and plants. Plant J. 29, 649-659. doi: 10.1046/j.0960-7412.2001.01247.x

Isbat, M., Zeba, N., Kim, S. R., and Hong, C. B. (2009). A BAX inhibitor-1 gene in Capsicum annuum is induced under various abiotic stresses and endows multi-tolerance in transgenic tobacco. J. Plant Physiol. 166, 1685-1693. doi: 10.1016/j.jplph.2009.04.017

Ishikawa, T., Watanabe, N., Nagano, M., Kawai-Yamada, M., and Lam, E. (2011). Bax inhibitor-1: a highly conserved endoplasmic reticulum-resident cell death suppressor. Cell Death. Differ. 18, 1271-1278. doi: 10.1038/cdd.2011.59

Iwata, Y., and Koizumi, N. (2005). An Arabidopsis transcription factor, AtbZIP60, regulates the endoplasmic reticulum stress response in a manner unique to plants. Proc. Natl. Acad. Sci. U.S.A. 102, 5280-5285. doi: 10.1073/pnas.0408941102

Jabs, T., Dietrich, R. A., and Dangl, J. L. (1996). Initiation of runaway cell death in an Arabidopsis mutant by extracellular superoxide. Science 273, 1853-1856. doi: $10.1126 /$ science.273.5283.1853

Jaspers, P., and Kangasjarvi, J. (2010). Reactive oxygen species in abiotic stress signaling. Physiol. Plant. 138, 405-413. doi: 10.1111/j.1399-3054.2009.01321.x

Jia, Y. J., Cheng, D. D., Wang, W. B., Gao, H. Y., Liu, A. X., Li, X. M., et al. (2010). Different enhancement of senescence induced by metabolic products of Alternaria alternata in tobacco leaves of different ages. Physiol. Plant. 138, 164-175. doi: 10.1111/j.1399-3054.2009.01300.x

Jin, C. W., Mao, Q. Q., Luo, B. F., Lin, X. Y., and Du, S. T. (2013). Mutation of mpk6 enhances cadmium tolerance in Arabidopsis plants by alleviating oxidative stress. Plant Soil 371, 387-396. doi: 10.1007/s11104-013-1699-8

Jing, H. C., Schippers, J. H., Hille, J., and Dijkwel, P. P. (2005). Ethylene-induced leaf senescence depends on age-related changes and OLD genes in Arabidopsis. J. Exp. Bot. 56, 2915-2923. doi: 10.1093/jxb/eri287

Jing, H. C., Sturre, M. J., Hille, J., and Dijkwel, P. P. (2002). Arabidopsis onset of leaf death mutants identify a regulatory pathway controlling leaf senescence. Plant J. 32, 51-63. doi: 10.1046/j.1365-313X.2002.01400.x

Jordan, D. B., and Ogren, W. L. (1984). The CO2/O2 specificity of ribulose 1,5-bisphosphate carboxylase/oxygenase: dpendence on ribulosebisphosphate concentration, $\mathrm{pH}$, and temperature. Planta 161, 308-313. doi: 10.1007/BF00 398720

Karpinski, S., Szechynska-Hebda, M., Wituszynska, W., and Burdiak, P. (2013). Light acclimation, retrograde signalling, cell death and immune defences in plants. Plant Cell Environ. 36, 736-744. doi: 10.1111/pce.12018

Kawai-Yamada, M., Ohori, Y., and Uchimiya, H. (2004). Dissection of Arabidopsis Bax inhibitor-1 suppressing Bax-, hydrogen peroxide-, and salicylic acid-induced cell death. Plant Cell 16, 21-32. doi: 10.1105/tpc.014613

Kehrer, J. P. (2000). The Haber-Weiss reaction and mechanisms of toxicity. Toxicology 149, 43-50. doi: 10.1016/S0300-483X(00)00231-6

Khanna-Chopra, R. (2012). Leaf senescence and abiotic stresses share reactive oxygen species-mediated chloroplast degradation. Protoplasma 249, 469-481. doi: 10.1007/s00709-011-0308-Z

Kim, Y., Wang, M., Bai, Y., Zeng, Z., Guo, F., Han, N., et al. (2014). Bcl-2 suppresses activation of VPEs by inhibiting cytosolic Ca2+ level with elevated $\mathrm{K}+$ efflux in NaCl-induced PCD in rice. Plant Physiol. Biochem. 80, 168-175. doi: 10.1016/j.plaphy.2014.04.002

Kliebenstein, D. J., Lim, J. E., Landry, L. G., and Last, R. L. (2002). Arabidopsis UVR8 regulates ultraviolet-B signal transduction and tolerance and contains sequence similarity to human regulator of chromatin condensation 1. Plant Physiol. 130, 234-243. doi: 10.1104/pp.005041

Koukalova, B., Kovarik, A., Fajkus, J., and Siroky, J. (1997). Chromatin fragmentation associated with apoptotic changes in tobacco cells exposed to cold stress. FEBS Lett. 414, 289-292. doi: 10.1016/S0014-5793(97)01008-9

Kovalchuk, I., Titov, V., Hohn, B., and Kovalchuk, O. (2005). Transcriptome profiling reveals similarities and differences in plant responses to cadmium and lead. Mutat. Res. 570, 149-161. doi: 10.1016/j.mrfmmm.2004.10.004 
Kranner, I., Beckett, R. P., Wornik, S., Zorn, M., and Pfeifhofer, H. W. (2002). Revival of a resurrection plant correlates with its antioxidant status. Plant J. 31, 13-24. doi: 10.1046/j.1365-313X.2002.01329.x

Kravchik, M., and Bernstein, N. (2013). Effects of salinity on the transcriptome of growing maize leaf cells point at cell-age specificity in the involvement of the antioxidative response in cell growth restriction. BMC Genomics 14:24. doi 10.1186/1471-2164-14-24

Kulms, D., and Schwarz, T. (2000). Molecular mechanisms of UV-induced apoptosis Photodermatol. Photoimmunol. Photomed. 16, 195-201. doi: 10.1034/j.1600 0781.2000.160501.x

Kwak, J. M., Mori, I. C., Pei, Z. M., Leonhardt, N., Torres, M. A., Dangl, J. L., et al. (2003). NADPH oxidase AtrbohD and AtrbohF genes function in ROS-dependent ABA signaling in Arabidopsis. EMBO J. 22, 2623-2633. doi: 10.1093/emboj/cdg277

Laloi, C., Stachowiak, M., Pers-Kamczyc, E., Warzych, E., Murgia, I., and Apel, K. (2007). Cross-talk between singlet oxygen- and hydrogen peroxide-dependen signaling of stress responses in Arabidopsis thaliana. Proc. Natl. Acad. Sci. U.S.A 104, 672-677. doi: 10.1073/pnas.0609063103

Lee, K. P., Kim, C., Landgraf, F., and Apel, K. (2007). EXECUTER1- and EXECUTER2-dependent transfer of stress-related signals from the plastid to the nucleus of Arabidopsis thaliana. Proc. Natl. Acad. Sci. U.S.A. 104, 10270-10275. doi: 10.1073/pnas.0702061104

Lee, S., Lee, H. J., Huh, S. U., Paek, K. H., Ha, J. H., and Park, C. M. (2014). The Arabidopsis NAC transcription factor NTL4 participates in a positive feedback loop that induces programmed cell death under heat stress conditions. Plant Sci. 227, 76-83. doi: 10.1016/j.plantsci.2014.07.003

Lee, S., Seo, P. J., Lee, H. J., and Park, C. M. (2012). A NAC transcription factor NTL4 promotes reactive oxygen species production during drought-induced leaf senescence in Arabidopsis. Plant J. 70, 831-844. doi: 10.1111/j.1365-313X.2012.04932.x

Lenochova, Z., Soukup, A., and Votrubova, O. (2009). Aerenchyma formation in maize roots. Biol. Plant. 53, 263-270. doi: 10.1007/s10535-009-0049-4

Li, Y., Chen, L., Mu, J., and Zuo, J. (2013). LESION SIMULATING DISEASE1 interacts with catalases to regulate hypersensitive cell death in Arabidopsis. Plant Physiol. 163, 1059-1070. doi: 10.1104/pp.113.225805

Li, Z., and Xing, D. (2010). Mitochondrial pathway leading to programmed cell death induced by aluminum phytotoxicity in Arabidopsis. Plant Signal. Behav. 5, 1660-1662. doi: 10.4161/psb.5.12.14014

Li, Z., Yue, H., and Xing, D. (2012). MAP kinase 6-mediated activation of vacuolar processing enzyme modulates heat shock-induced programmed cell death in Arabidopsis. New Phytol. 195, 85-96. doi: 10.1111/j.1469-8137.2012.04131.x

Lin, J., Wang, Y., and Wang, G. (2006). Salt stress-induced programmed cell death in tobacco protoplasts is mediated by reactive oxygen species and mitochondrial permeability transition pore status. J. Plant Physiol. 163, 731-739. doi 10.1016/j.jplph.2005.06.016

Liu, C., Zhao, L., and Yu, G. (2011). The dominant glutamic acid metabolic flux to produce gamma-amino butyric acid over proline in Nicotiana tabacum leaves under water stress relates to its significant role in antioxidant activity. J. Integr. Plant Biol. 53, 608-618. doi: 10.1111/j.1744-7909.2011.01049.x

Liu, J., Li, Z., Wang, Y., and Xing, D. (2014). Overexpression of ALTERNATIVE OXIDASE1a alleviates mitochondria-dependent programmed cell death induced by aluminium phytotoxicity in Arabidopsis. J. Exp. Bot. 65, 4465-4478. doi: 10.1093/jxb/eru222

Liu, J. X., Srivastava, R., Che, P., and Howell, S. H. (2007). An endoplasmic reticulum stress response in Arabidopsis is mediated by proteolytic processing and nuclear relocation of a membrane-associated transcription factor, bZIP28. Plant Cell 19 4111-4119. doi: 10.1105/tpc.106.050021

Liu, J., Wang, X., Hu, Y., Hu, W., and Bi, Y. (2013a). Glucose-6-phosphate dehydrogenase plays a pivotal role in tolerance to drought stress in soybean roots. Plant Cell Rep. 32, 415-429. doi: 10.1007/s00299-012-1374-1

Liu, K. L., Shen, L., and Sheng, J. P. (2008). Improvement in cadmium tolerance of tomato seedlings with an antisense DNA for 1-aminocyclopropane-1-carboxylate synthase. J. Plant Nutr. 31, 809-827. doi: 10.1080/01904160802043080

Liu, Y. H., Offler, C. E., and Ruan, Y. L. (2013b). Regulation of fruit and seed response to heat and drought by sugars as nutrients and signals. Front. Plant Sci. 4:282 doi: $10.3389 /$ fpls.2013.00282

Logan, D. C., and Leaver, C. J. (2000). Mitochondria-targeted GFP highlights the heterogeneity of mitochondrial shape, size, and movement within living plant cells. J. Exp. Bot. 51, 865-871. doi: 10.1093/jexbot/51.346.865
Luo, H., Laluk, K., Lai, Z., Veronese, P., Song, F., and Mengiste, T. (2010). The Arabidopsis botrytis susceptiblel interactor defines a subclass of RING E3 ligases that regulate pathogen and stress responses. Plant Physiol. 154, 1766-1782. doi: 10.1104/pp.110.163915

Lv, W. T., Lin, B., Zhang, M., and Hua, X. J. (2011). Proline accumulation is inhibitory to Arabidopsis seedlings during heat stress. Plant Physiol. 156, 19211933. doi: 10.1104/pp.111.175810

Lyubushkina, I. V., Grabelnych, O. I., Pobezhimova, T. P., Stepanov, A. V., Fedyaeva, A. V., Fedoseeva, I. V., et al. (2014). Winter wheat cells subjected to freezing temperature undergo death process with features of programmed cell death. Protoplasma 251, 615-623. doi: 10.1007/s00709-013-0562-3

Majer, P., Czegeny, G., Sandor, G., Dix, P. J., and Hideg, E. (2014). Antioxidant defence in UV-irradiated tobacco leaves is centred on hydrogen-peroxide neutralization. Plant Physiol. Biochem. 82, 239-243. doi: 10.1016/j.plaphy.2014.06.011

Marsoni, M., Cantara, C., De Pinto, M. C., Gadaleta, C., De Gara, L., Bracale, M., et al. (2010). Exploring the soluble proteome of tobacco bright yellow-2 cells at the switch towards different cell fates in response to heat shocks. Plant Cell Environ. 33, 1161-1175. doi: 10.1111/j.1365-3040.2010.02137.x

Mateo, A., Muhlenbock, P., Rusterucci, C., Chang, C. C., Miszalski, Z., Karpinska, B., et al. (2004). LESION SIMULATING DISEASE 1 is required for acclimation to conditions that promote excess excitation energy. Plant Physiol. 136, 2818-2830. doi: 10.1104/pp.104.043646

Mathur, S., Agrawal, D., and Jajoo, A. (2014). Photosynthesis: response to high temperature stress. J. Photochem. Photobiol. B 137, 116-126. doi: 10.1016/j.jphotobiol.2014.01.010

Mendes, G. C., Reis, P. A., Calil, I. P., Carvalho, H. H., Aragao, F. J., and Fontes, E. P. (2013). GmNAC30 and GmNAC81 integrate the endoplasmic reticulum stress- and osmotic stress-induced cell death responses through a vacuolar processing enzyme. Proc. Natl. Acad. Sci. U.S.A. 110, 19627-19632. doi: 10.1073/pnas. 1311729110

Meskauskiene, R., Wursch, M., Laloi, C., Vidi, P. A., Coll, N. S., Kessler, F., et al. (2009). A mutation in the Arabidopsis mTERF-related plastid protein SOLDAT10 activates retrograde signaling and suppresses $1 \mathrm{O} 2$-induced cell death. Plant J. 60, 399-410. doi: 10.1111/j.1365-313X.2009.03965.x

Miller, G., and Mittler, R. (2006). Could heat shock transcription factors function as hydrogen peroxide sensors in plants? Ann. Bot. 98, 279-288. doi: 10.1093/aob/mcl107

Miller, G., Suzuki, N., Ciftci-Yilmaz, S., and Mittler, R. (2010). Reactive oxygen species homeostasis and signalling during drought and salinity stresses. Plant Cell Environ. 33, 453-467. doi: 10.1111/j.1365-3040.2009.02041.x

Mittler, R., and Blumwald, E. (2010). Genetic engineering for modern agriculture: challenges and perspectives. Annu. Rev. Plant Biol. 61, 443-462. doi: 10.1146/annurev-arplant-042809-112116

Monetti, E., Kadono, T., Tran, D., Azzarello, E., Arbelet-Bonnin, D., Biligui, B., et al. (2014). Deciphering early events involved in hyperosmotic stress-induced programmed cell death in tobacco BY-2 cells. J. Exp. Bot. 65, 1361-1375. doi: $10.1093 /$ jxb/ert460

Moreno, A. A., and Orellana, A. (2011). The physiological role of the unfolded protein response in plants. Biol. Res. 44, 75-80. doi: 10.4067/S071697602011000100010

Moschou, P. N., Paschalidis, K. A., Delis, I. D., Andriopoulou, A. H., Lagiotis, G. D., Yakoumakis, D. I., et al. (2008). Spermidine exodus and oxidation in the apoplast induced by abiotic stress is responsible for $\mathrm{H} 2 \mathrm{O} 2$ signatures that direct tolerance responses in tobacco. Plant Cell 20, 1708-1724. doi: 10.1105/tpc.108. 059733

Muhlenbock, P., Szechynska-Hebda, M., Plaszczyca, M., Baudo, M., Mateo, A., Mullineaux, P. M., et al. (2008). Chloroplast signaling and LESION SIMULATING DISEASE1 regulate crosstalk between light acclimation and immunity in Arabidopsis. Plant Cell 20, 2339-2356. doi: 10.1105/tpc.108. 059618

Mullineaux, P. M., Karpinski, S., and Baker, N. R. (2006). Spatial dependence for hydrogen peroxide-directed signaling in light-stressed plants. Plant Physiol. 141, 346-350. doi: 10.1104/pp.106.078162

Munné-Bosch, S., and Alegre, L. (2002). Plant aging increases oxidative stress in chloroplasts. Planta 214, 608-615. doi: 10.1007/s004250100646

Munné-Bosch, S., and Alegre, L. (2004). Die and let live: leaf senescence contributes to plant survival under drought stress. Funct. Plant. Biol. 31, 203-216. doi: 10.1071/FP03236 
Murata, N., Takahashi, S., Nishiyama, Y., and Allakhverdiev, S. I. (2007). Photoinhibition of photosystem II under environmental stress. Biochim. Biophys. Acta 1767, 414-421. doi: 10.1016/j.bbabio.2006.11.019

Murphy, T. M., and Huerta, A. J. (1990). Hydrogen-peroxide formation in cultured rose cells in response to Uv-C radiation. Physiol. Plant. 78, 247-253. doi: 10.1111/j.1399-3054.1990.tb02088.x

Nawkar, G. M., Maibam, P., Park, J. H., Sahi, V. P., Lee, S. Y., and Kang, C. H. (2013). UV-induced cell death in plants. Int. J. Mol. Sci. 14, 1608-1628. doi: 10.3390/ijms 14011608

Nishizawa, A., Yabuta, Y., and Shigeoka, S. (2008). Galactinol and raffinose constitute a novel function to protect plants from oxidative damage. Plant Physiol. 147, 1251-1263. doi: 10.1104/pp.108.122465

Nguyen, G. N., Hailstones, D. L., Wilkes, M., and Sutton, B. G. (2009). Droughtinduced oxidative conditions in rice anthers leading to a programmed cell death and pollen abortion. J. Agron. Crop Sci. 195, 157-164. doi: 10.1111/j.1439037X.2008.00357.x

Noctor, G., Veljovic-Jovanovic, S., Driscoll, S., Novitskaya, L., and Foyer, C. H. (2002). Drought and oxidative load in the leaves of C3 plants: a predominant role for photorespiration? Ann. Bot. 89, 841-850. doi: 10.1093/aob/mcf096

op den Camp, R. G. L., Przybyla, D., Ochsenbein, C., Laloi, C., Kim, C., Danon, A., et al. (2003). Rapid induction of distinct stress responses after the release of singlet oxygen in Arabidopsis. Plant Cell 15, 2320-2332. doi: 10.1105/tpc.014662

Osakabe, Y., Osakabe, K., Shinozaki, K., and Tran, L. S. (2014). Response of plants to water stress. Front. Plant Sci. 5:86. doi: 10.3389/fpls.2014.00086

Ott, M., Gogvadze, V., Orrenius, S., and Zhivotovsky, B. (2007). Mitochondria oxidative stress, and cell death. Apoptosis 12, 913-922. doi: 10.1007/s10495-0070756-2

Parlanti, S., Kudahettige, N. P., Lombardi, L., Mensuali-Sodi, A., Alpi, A., Perata, P., et al. (2011). Distinct mechanisms for aerenchyma formation in leaf sheaths of rice genotypes displaying a quiescence or escape strategy for flooding tolerance. Ann. Bot. 107, 1335-1343. doi: 10.1093/aob/mcr086

Petrov, V. D., and Van Breusegem, F. (2012). Hydrogen peroxide-a central hub for information flow in plant cells. AoB Plants 2012, pls014. doi: 10.1093/aob$\mathrm{pla} / \mathrm{pls} 014$

Piterkova, J., Luhova, L., Mieslerova, B., Lebeda, A., and Petrivalsky, M. (2013). Nitric oxide and reactive oxygen species regulate the accumulation of heat shock proteins in tomato leaves in response to heat shock and pathogen infection. Plan Sci. 207, 57-65. doi: 10.1016/j.plantsci.2013.02.010

Puniran-Hartley, N., Hartley, J., Shabala, L., and Shabala, S. (2014). Salinity-induced accumulation of organic osmolytes in barley and wheat leaves correlates with increased oxidative stress tolerance: in planta evidence for cross-tolerance. Plant Physiol. Biochem. 83C, 32-39. doi: 10.1016/j.plaphy.2014.07.005

Qi, Y., Wang, H., Zou, Y., Liu, C., Liu, Y., Wang, Y., et al. (2011). Over-expression of mitochondrial heat shock protein 70 suppresses programmed cell death in rice. FEBS Lett. 585, 231-239. doi: 10.1016/j.febslet.2010.11.051

Radeva, V., Petrov, V., Minkov, I., Toneva, V., and Gechev, T. (2010). Effect of cadmium on Arabidopsis thaliana mutants tolerant to oxidative stress. Biotechnol. Biotechnol. Equip. 24, 113-118. doi: 10.1080/13102818.2010.1081782

Rajhi, I., Yamauchi, T., Takahashi, H., Nishiuchi, S., Shiono, K., Watanabe, R., et al. (2011). Identification of genes expressed in maize root cortical cells during lysigenous aerenchyma formation using laser microdissection and microarray analyses. New Phytol. 190, 351-368. doi: 10.1111/j.1469-8137.2010.03535.x

Ramel, F., Ksas, B., Akkari, E., Mialoundama, A. S., Monnet, F., Krieger-Liszkay, A., et al. (2013). Light-induced acclimation of the Arabidopsis chlorinal mutant to singlet oxygen. Plant Cell 25, 1445-1462. doi: 10.1105/tpc.113.109827

Rampino, P., Mita, G., Fasano, P., Borrelli, G. M., Aprile, A., Dalessandro, G., et al. (2012). Novel durum wheat genes up-regulated in response to a combination of heat and drought stress. Plant Physiol. Biochem. 56, 72-78. doi: 10.1016/j.plaphy.2012.04.006

Reape, T. J., and McCabe, P. F. (2008). Apoptotic-like programmed cell death in plants. New Phytol. 180, 13-26. doi: 10.1111/j.1469-8137.2008.02549.x

Reginato, M. A., Castagna, A., Furlan, A., Castro, S., Ranieri, A., and Luna, V. (2014). Physiological responses of a halophytic shrub to salt stress by $\mathrm{Na} 2 \mathrm{SO} 4$ and $\mathrm{NaCl}$ : oxidative damage and the role of polyphenols in antioxidant protection. $A o B$ Plants 6, pii: plu042. doi: 10.1093/aobpla/plu042

Rizzini, L., Favory, J. J., Cloix, C., Faggionato, D., O’hara, A., Kaiserli, E., et al. (2011). Perception of UV-B by the Arabidopsis UVR8 protein. Science 332, 103-106. doi: $10.1126 /$ science. 1200660
Rodriguez-Serrano, M., Romero-Puertas, M. C., Pazmino, D. M., Testillano, P. S., Risueno, M. C., Del Rio, L. A., et al. (2009). Cellular response of pea plants to cadmium toxicity: cross talk between reactive oxygen species, nitric oxide, and calcium. Plant Physiol. 150, 229-243. doi: 10.1104/pp.108.131524

Rosenzweig, C., Elliott, J., Deryng, D., Ruane, A. C., Muller, C., Arneth, A., et al. (2014). Assessing agricultural risks of climate change in the 21 st century in a global gridded crop model intercomparison. Proc. Natl. Acad. Sci. U.S.A. 111, 3268-3273. doi: 10.1073/pnas.1222463110

Samac, D. A., and Tesfaye, M. (2003). Plant improvement for tolerance to aluminum in acid soils - a review. Plant Cell Tissue Organ. Cult. 75, 189-207. doi: 10.1023/A:1025843829545

Samol, I., Buhr, F., Springer, A., Pollmann, S., Lahroussi, A., Rossig, C., et al. (2011). Implication of the oep 16-1 mutation in a flu-independent, singlet oxygenregulated cell death pathway in Arabidopsis thaliana. Plant Cell Physiol. 52, 84-95. doi: $10.1093 / \mathrm{pcp} / \mathrm{pcq} 176$

Shabala, S. (2009). Salinity and programmed cell death: unravelling mechanisms for ion specific signalling. J. Exp. Bot. 60, 709-712. doi: 10.1093/jxb/erp013

Shabala, S., Shabala, L., Barcelo, J., and Poschenrieder, C. (2014). Membrane transporters mediating root signalling and adaptive responses to oxygen deprivation and soil flooding. Plant Cell Environ. 37, 2216-2233. doi: 10.1111/pce.12339

Sharma, P. N., Kumar, P., and Tewari, R. K. (2004). Early signs of oxidative stress in wheat plants subjected to zinc deficiency. J. Plant Nutr. 27, 451-463. doi: 10.1081/Pln-120028873

Sperdouli, I., and Moustakas, M. (2014). Leaf developmental stage modulates metabolite accumulation and photosynthesis contributing to acclimation of Arabidopsis thaliana to water deficit. J. Plant Res. 127, 481-489. doi: 10.1007/s10265-014-0635-1

Steffens, B., Geske, T., and Sauter, M. (2011). Aerenchyma formation in the rice stem and its promotion by H2O2. New Phytol. 190, 369-378. doi: 10.1111/j.14698137.2010.03496.x

Steffens, B., Kovalev, A., Gorb, S. N., and Sauter, M. (2012). Emerging roots alter epidermal cell fate through mechanical and reactive oxygen species signaling. Plant Cell 24, 3296-3306. doi: 10.1105/tpc.112.101790

Stieger, P. A., and Feller, U. (1997). Degradation of stromal proteins in pea (Pisum sativum L) chloroplasts under oxidising conditions. J. Plant Physiol. 151, 556562. doi: 10.1016/S0176-1617(97)80230-1

Sunkar, R., Bartels, D., and Kirch, H. H. (2003). Overexpression of a stressinducible aldehyde dehydrogenase gene from Arabidopsis thaliana in transgenic plants improves stress tolerance. Plant J. 35, 452-464. doi: 10.1046/j.1365313X.2003.01819.x

Suzuki, N., Koussevitzky, S., Mittler, R., and Miller, G. (2012). ROS and redox signalling in the response of plants to abiotic stress. Plant Cell Environ. 35, 259270. doi: 10.1111/j.1365-3040.2011.02336.x

Szabados, L., and Savoure, A. (2010). Proline: a multifunctional amino acid. Trends Plant Sci. 15, 89-97. doi: 10.1016/j.tplants.2009.11.009

Szechynska-Hebda, M., and Karpinski, S. (2013). Light intensity-dependent retrograde signalling in higher plants. J. Plant Physiol. 170, 1501-1516. doi: 10.1016/j.jplph.2013.06.005

Szechynska-Hebda, M., Kruk, J., Gorecka, M., Karpinska, B., and Karpinski, S. (2010). Evidence for light wavelength-specific photoelectrophysiological signaling and memory of excess light episodes in Arabidopsis. Plant Cell 22, 2201-2218. doi: $10.1105 /$ tpc. 109.069302

Teakle, N. L., and Tyerman, S. D. (2010). Mechanisms of Cl- transport contributing to salt tolerance. Plant Cell Environ. 33, 566-589. doi: 10.1111/j.13653040.2009.02060.x

Tester, M., and Langridge, P. (2010). Breeding technologies to increase crop production in a changing world. Science 327, 818-822. doi: 10.1126/science. 1 183700

Toumi, I., Moschou, P. N., Paschalidis, K. A., Bouamama, B., Ben Salem-Fnayou, A., Ghorbel, A. W., et al. (2010). Abscisic acid signals reorientation of polyamine metabolism to orchestrate stress responses via the polyamine exodus pathway in grapevine. J. Plant Physiol. 167, 519-525. doi: 10.1016/j.jplph.2009.10.022

Triantaphylides, C., Krischke, M., Hoeberichts, F. A., Ksas, B., Gresser, G., Havaux, M., et al. (2008). Singlet oxygen is the major reactive oxygen species involved in photooxidative damage to plants. Plant Physiol. 148, 960-968. doi: 10.1104/pp.108.125690

Tsutsui, T., Kato, W., Asada, Y., Sako, K., Sato, T., Sonoda, Y., et al. (2009). DEAR1, a transcriptional repressor of DREB protein that mediates plant defense 
and freezing stress responses in Arabidopsis. J. Plant Res. 122, 633-643. doi: 10.1007/s10265-009-0252-6

Ueda, T., and Nakamura, C. (2011). Ultraviolet-defense mechanisms in higher plants. Biotechnol. Biotechnol. Equip. 25, 2177-2182. doi: 10.5504/Bbeq.2011.0001

Vacca, R. A., De Pinto, M. C., Valenti, D., Passarella, S., Marra, E., and De Gara, L. (2004). Production of reactive oxygen species, alteration of cytosolic ascorbate peroxidase, and impairment of mitochondrial metabolism are early events in heat shock-induced programmed cell death in tobacco Bright-Yellow 2 cells. Plant Physiol. 134, 1100-1112. doi: 10.1104/pp.103.035956134/3/1100

Vacca, R. A., Valenti, D., Bobba, A., Merafina, R. S., Passarella, S., and Marra, E. (2006). Cytochrome $\mathrm{c}$ is released in a reactive oxygen species-dependent manner and is degraded via caspase-like proteases in tobacco Bright-Yellow 2 cells en route to heat shock-induced cell death. Plant Physiol. 141, 208-219. doi: $10.1104 /$ pp.106.078683

Van Breusegem, F., and Dat, J. F. (2006). Reactive oxygen species in plant cell death. Plant Physiol. 141, 384-390. doi: 10.1104/pp.106.078295

Vandenabeele, S., Van Der Kelen, K., Dat, J., Gadjev, I., Boonefaes, T., Morsa, S., et al. (2003). A comprehensive analysis of hydrogen peroxide-induced gene expression in tobacco. Proc. Natl. Acad. Sci. U.S.A. 100, 16113-16118. doi: 10.1073/pnas.2136610100f

Verbruggen, N., and Hermans, C. (2008). Proline accumulation in plants: a review. Amino Acids 35, 753-759. doi: 10.1007/s00726-008-0061-6

Wang, C., Zhang, S. H., Wang, P. F., Hou, J., Zhang, W. J., Li, W., et al. (2009). The effect of excess $\mathrm{Zn}$ on mineral nutrition and antioxidative response in rapeseed seedlings. Chemosphere 75, 1468-1476. doi: 10.1016/j.chemosphere.2009.02.033

Wang, X., Cai, J., Liu, F. L., Dai, T. B., Cao, W. X., Wollenweber, B., et al. (2014) Multiple heat priming enhances thermo-tolerance to a later high temperature stress via improving subcellular antioxidant activities in wheat seedlings. Plant Physiol. Biochem. 74, 185-192. doi: 10.1016/j.plaphy.2013.11.014

Watanabe, N., and Lam, E. (2006). Arabidopsis Bax inhibitor-1 functions as an attenuator of biotic and abiotic types of cell death. Plant J. 45, 884-894. doi: 10.1111/j.1365-313X.2006.02654.x

Watanabe, N., and Lam, E. (2009). Bax Inhibitor-1, a conserved cell death suppressor is a key molecular switch downstream from a variety of biotic and abiotic stress signals in plants. Int. J. Mol. Sci. 10, 3149-3167. doi: 10.3390/ijms10073149

Wiermer, M., Feys, B. J., and Parker, J. E. (2005). Plant immunity: the EDS1 regulatory node. Curr. Opin. Plant Biol. 8, 383-389. doi: 10.1016/j.pbi.2005.05.010

Wilhelm, C., and Selmar, D. (2011). Energy dissipation is an essential mechanism to sustain the viability of plants: the physiological limits of improved photosynthesis. J. Plant Physiol. 168, 79-87. doi: 10.1016/j.jplph.2010.07.012

Williams, B., Verchot, J., and Dickman, M. B. (2014). When supply does not meet demand-ER stress and plant programmed cell death. Front. Plant Sci. 5:211. doi: 10.3389/fpls.2014.00211

Wingler, A., Lea, P. J., Quick, W. P., and Leegood, R. C. (2000). Photorespiration: metabolic pathways and their role in stress protection. Philos. Trans. R. Soc. Lond. B Biol. Sci. 355, 1517-1529. doi: 10.1098/rstb.2000.0712

Wituszynska, W., Szechynska-Hebda, M., Sobczak, M., Rusaczonek, A., KozlowskaMakulska, A., Witon, D., et al. (2014). LESION SIMULATING DISEASE 1 and ENHANCED DISEASE SUSCEPTIBILITY 1 differentially regulate UVC-induced photooxidative stress signalling and programmed cell death in Arabidopsis thaliana. Plant Cell Environ. 38, 315-330. doi: 10.1111/pce.12288

Xu, H., Xu, W., Xi, H., Ma, W., He, Z., and Ma, M. (2013). The ER luminal binding protein $(\mathrm{BiP})$ alleviates $\mathrm{Cd} 2+$-induced programmed cell death through endoplasmic reticulum stress-cell death signaling pathway in tobacco cells. J. Plant Physiol. 170, 1434-1441. doi: 10.1016/j.jplph.2013.05.017

$\mathrm{Xu}$, J., Yin, H., Li, Y., and Liu, X. (2010). Nitric oxide is associated with longterm zinc tolerance in Solanum nigrum. Plant Physiol. 154, 1319-1334. doi: $10.1104 /$ pp. 110.162982
Yakimova, E. T., Kapchina-Toteva, V. M., Laarhoven, L. J., Harren, F. M., and Woltering, E. J. (2006). Involvement of ethylene and lipid signalling in cadmium-induced programmed cell death in tomato suspension cells. Plant Physiol. Biochem. 44, 581-589. doi: 10.1016/j.plaphy.2006.09.003

Yakimova, E. T., Kapchina-Toteva, V. M., and Woltering, E. J. (2007). Signal transduction events in aluminum-induced cell death in tomato suspension cells. J. Plant Physiol. 164, 702-708. doi: 10.1016/j.jplph.2006.03.018

Yamauchi, T., Watanabe, K., Fukazawa, A., Mori, H., Abe, F., Kawaguchi, K., et al. (2014). Ethylene and reactive oxygen species are involved in root aerenchyma formation and adaptation of wheat seedlings to oxygen-deficient conditions. J. Exp. Bot. 65, 261-273. doi: 10.1093/jxb/ert371

Yang, Z. T., Wang, M. J., Sun, L., Lu, S. J., Bi, D. L., Song, Z. T., et al. (2014). The membrane-associated transcription factor NAC089 controls ERstress-induced programmed cell death in plants. PLoS Genet 10:e1004243. doi: 10.1371/journal.pgen.1004243

Yao, N., Eisfelder, B. J., Marvin, J., and Greenberg, J. T. (2004). The mitochondrionan organelle commonly involved in programmed cell death in Arabidopsis thaliana. Plant J. 40, 596-610. doi: 10.1111/j.1365-313X.2004.02239.x

Yoon, J. Y., Shin, J. S., Shin, D. Y., Hyun, K. H., Burgos, N. R., Lee, S., et al. (2011). Tolerance to paraquat-mediated oxidative and environmental stresses in squash (Cucurbita spp.) leaves of various ages. Pest. Biochem. Physiol. 99, 65-76. doi: 10.1016/j.pestbp.2010.11.001

Zhang, L., Li, Y., Xing, D., and Gao, C. (2009a). Characterization of mitochondrial dynamics and subcellular localization of ROS reveal that HsfA2 alleviates oxidative damage caused by heat stress in Arabidopsis. J. Exp. Bot. 60, 2073-2091. doi: 10.1093/jxb/erp078

Zhang, L., Xu, Q., Xing, D., Gao, C., and Xiong, H. (2009b). Real-time detection of caspase-3-like protease activation in vivo using fluorescence resonance energy transfer during plant programmed cell death induced by ultraviolet C overexposure. Plant Physiol. 150, 1773-1783. doi: 10.1104/pp.108. 125625

Zhang, Q., Su, L. J., Chen, J. W., Zeng, X. Q., Sun, B. Y., and Peng, C. L. (2012) The antioxidative role of anthocyanins in Arabidopsis under high-irradiance. Biol. Plant. 56, 97-104. doi: 10.1007/s10535-011-0218-0

Zhang, X., Liu, S., and Takano, T. (2008). Two cysteine proteinase inhibitors from Arabidopsis thaliana, AtCYSa and AtCYSb, increasing the salt, drought, oxidation, and cold tolerance. Plant Mol. Biol. 68, 131-143. doi: 10.1007/s11103-008-9357-x

Zhang, X., Wang, L., Meng, H., Wen, H., Fan, Y., and Zhao, J. (2011). Maize ABP9 enhances tolerance to multiple stresses in transgenic Arabidopsis by modulating ABA signaling and cellular levels of reactive oxygen species. Plant Mol. Biol. 75, 365-378. doi: 10.1007/s11103-011-9732-x

Conflict of Interest Statement: The authors declare that the research was conducted in the absence of any commercial or financial relationships that could be construed as a potential conflict of interest.

Received: 31 October 2014; accepted: 26 January 2015; published online: 18 February 2015.

Citation: Petrov V, Hille J, Mueller-Roeber B and Gechev TS (2015) ROS-mediated abiotic stress-induced programmed cell death in plants. Front. Plant Sci. 6:69. doi: 10.3389/fpls.2015.00069

This article was submitted to Plant Physiology, a section of the journal Frontiers in Plant Science.

Copyright (C) 2015 Petrov, Hille, Mueller-Roeber and Gechev. This is an open-access article distributed under the terms of the Creative Commons Attribution License (CC BY). The use, distribution or reproduction in other forums is permitted, provided the original author(s) or licensor are credited and that the original publication in this journal is cited, in accordance with accepted academic practice. No use, distribution or reproduction is permitted which does not comply with these terms. 